\title{
THE COST OF PRIVATE DEBT COVENANT VIOLATION
}

\author{
Scott D. Dyreng
}

A dissertation submitted to the faculty of the University of North Carolina at Chapel Hill in partial fulfillment of the requirements for the degree of Doctor of Philosophy in the Kenan-Flagler School of Business.

Chapel Hill

2008

Approved by:

Edward L. Maydew

Robert M. Bushman

John R. Graham

Wayne R. Landsman

Douglas A. Shackelford 


\section{ABSTRACT \\ SCOTT D. DYRENG: The Cost of Private Debt Covenant Violation (Under the direction of Edward L. Maydew)}

This study quantifies costs that firms are willing to incur to avoid violation of private debt covenants. The results indicate that as firms approach covenant violation they engage in income-increasing earnings management, which increases their tax liability. By estimating the extent of income-increasing activities and the additional tax costs incurred, this study arrives at a lower-bound estimate of the cost of violating private debt covenants. The mean (median) firm with relatively tight debt covenants increases its current tax liability by an amount equivalent to increasing the cost of debt financing by between $12.92(10.72)$ and $22.72(12.81)$ basis points (where firms with relatively loose debt covenants serve as the baseline). The magnitude of this estimate indicates that the expected costs of covenant violation are meaningful. Combined with recent evidence that private debt covenant violations occur frequently (Dichev and Skinner, 2002; Roberts and Sufi, 2007a), this implies debt covenants and expected violations are economically important. 


\section{ACKNOWLEDGEMENTS}

I am thankful for the dedicated support of my wife, Chelsea. Without her encouragement, this project would have been impossible. I appreciate the helpful comments of my dissertation committee: Ed Maydew (Chair), Robert Bushman, John Graham, Wayne Landsman, and Doug Shackelford. I also appreciate comments from

Ryan Ball, Kevin Markle, Ed Owens, Jana Raedy, Derrald Stice, Jake Thornock, Chris Williams. 


\section{TABLE OF CONTENTS}

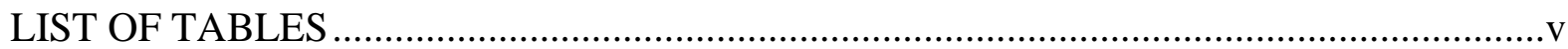

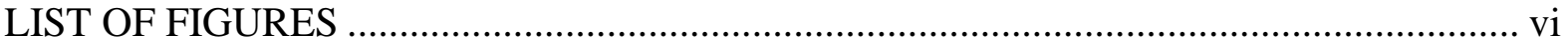

THE COST OF PRIVATE DEBT COVENANT VIOLATION ...........................................1

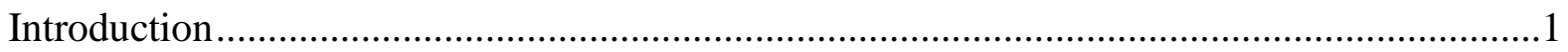

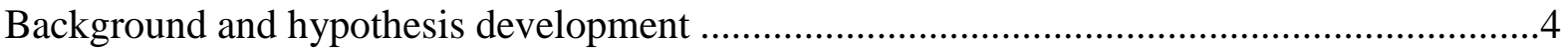

Sample selection and descriptive statistics .......................................................... 10

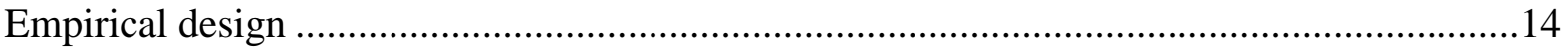

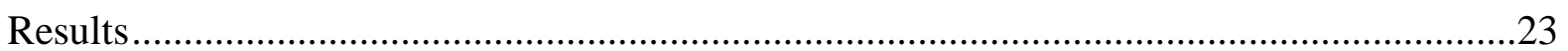

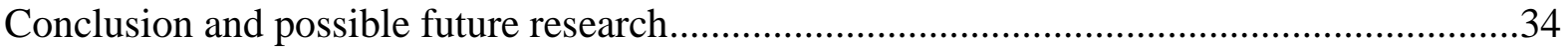

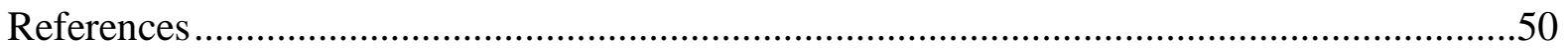




\section{LIST OF TABLES}

Table

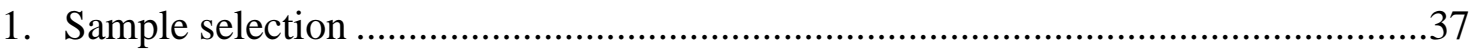

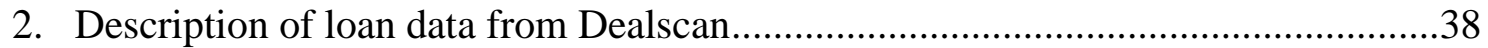

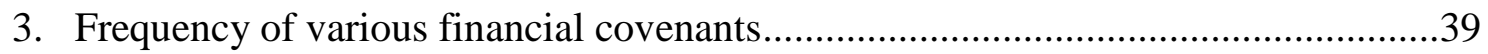

4. Estimation of the rate of conformity between taxable

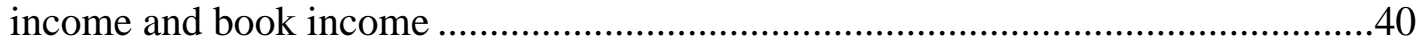

5. Descriptive statistics of variables used in tests of the relation between incremental tax expense and financial reporting pressure

6. Test of incremental tax expense and financial reporting pressure from debt covenants

7. Piecewise non-linear test of incremental tax expense and financial reporting pressure from debt covenants

8. Calculation of a lower bound on the cost of private debt covenant violation .46

9. Additional computations of the cost of debt covenant violation and comparison of the cost of debt covenant violation to various benchmarks 


\section{LIST OF FIGURES}

Figure

1. Relation between estimated debt covenant slack $(S L A C K)$ and incremental tax expense ....

2. Evolution of incremental tax relative to quarter with the tightest decile of debt covenant slack 


\section{Introduction}

The influence of debt on corporate decisions has been studied for decades in the accounting and finance literatures. One consistent finding in this literature is that private debt covenants are violated frequently (Dichev and Skinner, 2002; Roberts and Sufi, 2007a; Roberts and Sufi, 2007b). Because of the frequency of private debt covenant violations, some have suggested the costs of violation are low (Dichev and Skinner, 2002; Duke and Hunt, 1990). Others have argued that the costs are high because firms are sometimes forced to make substantial concessions to lenders when renegotiating private credit agreements that contain financial covenants (Roberts and Sufi, 2007a; Nini, Roberts and Sufi, 2007). Surprisingly, little research exists that quantifies the costs of private debt covenant violation. In this paper, I begin to fill this gap in the literature by estimating a lower-bound on the cost of debt covenant violation in private credit agreements.

I draw on two established lines of research in developing lower-bound estimates of the cost of private debt covenant violation. One branch of research examines financial accounting incentives arising from debt covenants (e.g., Watts and Zimmerman, 1986; Beatty and Weber, 2003; Beatty, Ramesh, and Weber, 2002; Defond and Jiambalvo, 1994; Sweeney, 1994). Another branch of research examines the decisions firms make when trading off the opposing incentives created by financial accounting and taxes (e.g., Hunt, Moyer, and Shevlin, 1996; Dhaliwal, Frankel, and Trezevant, 1994; Johnson and Dhaliwal, 1988). I use techniques and insights from these literatures to test whether firms 
that have covenants in their private credit agreements incur incremental tax costs in the process of managing earnings to avoid debt covenant violation.

Incremental tax costs may arise if the expected costs of covenant violation are greater than the expected costs associated with managing financial results to avoid covenant violation. Borrowing firms have incentives to report performance that falls above covenant thresholds (Watts and Zimmerman, 1986; Dichev \& Skinner, 2002; Nini et al., 2007). As covenant slack tightens, these firms face greater pressure to make accounting choices that have an immediate favorable impact on reported performance. Because taxable income is positively correlated with accounting income, increases in accounting income can cause increases in tax expense. Thus, firms may be forced to trade the benefits of avoiding covenant violations against the costs of increasing taxable income.

On the other hand, firms may be able to increase reported earnings using techniques that do not increase taxes. For example, Baderstcher et al. (2007) find that firms are sometimes able to increase accounting income without increasing taxable income. That is, firms may use accounting methods or transactions that have a low rate of book-tax conformity, where book-tax conformity refers to the correspondence between accounting income and taxable income. In addition, variation in marginal tax rates across firms may mitigate the actual tax expense incurred on increases in accounting income, even if the accounting income must be recognized as taxable income. For example, a firm with substantial net operating loss carryforwards may be able to increase accounting earnings in a way that conforms to taxable income without actually increasing taxes in the current period. 
The primary purpose of this paper is to estimate the average firm's incremental tax cost resulting from actions taken to relieve debt covenant pressure. Taking into consideration the rate of book-tax conformity and the marginal tax rate, and controlling for a variety of factors that may influence the firm's incremental tax burden, I find that firms with tighter debt covenants incur more current tax expense than they would if they had more debt covenant slack or if they did not have debt covenants. Estimates of incremental tax costs suggest that the mean (median) firm with relatively tight debt covenants increased its tax liability by an amount equivalent to increasing the cost of debt financing between 12.92 (10.72) and 22.72 (12.81) basis points, where firms with relatively loose debt covenants serve as the baseline. This result is evidence of a tax cost induced by debt covenants. The bright line financial targets created by debt covenant thresholds encourage firms to make accounting choices that immediately increase accounting income, and consequently increase the firm's tax burden. All else equal, firms with more debt covenant pressure pay more tax than they would if they had no debt covenants.

This finding creates a counterintuitive contrast with capital structure research in finance that documents tax benefits of debt. That is, while debt may provide the firm with a tax benefit due to the deductibility of interest (Modigliani and Miller, 1963), the tax benefit is in part offset by additional tax costs the firm bears as a result of debt covenant pressure.

This study contributes to the literature examining the costs and benefits of debt covenants. For example, debt covenants have been shown to reduce the cost of borrowing (Bradley and Roberts, 2004), to increase borrowing capacity (Boot, 2000; 
Petersen and Rajan, 1994), and to provide incentives for lenders to monitor the firm (Asquith, Beatty and Weber, 2005; Booth, 1992; Rajan and Winton, 1995). Naturally, these benefits come at a cost. I show that debt covenants lead firms to make accounting decisions that have real economic consequences in terms of incremental tax expense. Thus, increased tax expense from greater financial reporting pressure is one cost firms should consider when negotiating debt contracts. Moreover, these findings may also partially explain why firms are underlevered. Graham (2000) finds that the typical firm could double tax benefits by issuing debt until marginal tax benefits begin to decline. However, his analysis does not account for the possibility that the incentives to engage in income-increasing earnings management may change when levels of debt change, leading to increased tax costs.

This paper proceeds as follows. Section 2 gives background information and develops the hypothesis. Section 3 describes the sample selection. Section 4 outlines the empirical design. Section 5 presents the empirical results. Section 6 provides concluding remarks.

\section{Background and Hypothesis Development}

The purpose of this paper is to investigate whether firms incur additional tax costs because of financial reporting pressures created by debt covenants, and to quantify such costs in terms of relevant benchmarks. To develop my hypothesis, I draw on techniques and insights from two established streams of literature. First, I draw on prior research that tests the relation between debt covenants and accounting outcomes. Second, I draw on prior research that examines the relation between financial reporting costs and book-tax 
conformity. Combining the intuition from these two literatures, I develop and formally state my hypothesis.

\subsection{Debt covenants and accounting outcomes}

Debt covenants are one mechanism used by lenders to monitor the economic performance of borrowers (Asquith, Beatty, and Weber, 2005; Booth, 1992; Rajan and Winton, 1995; Smith and Warner, 1979). In exchange for the right to set performance benchmarks, lenders grant more favorable loan terms and/or more credit to borrowers. For example, Bradley and Roberts (2004) find a negative relation between financial covenants and loan price. Specifically, they find that increasing the likelihood that a firm has financial covenants by $50 \%$ decreases the expected cost of the loan by $1 \%$. Studies by Boot (2000), and Petersen and Rajan (1994) suggest that financial covenants are correlated with increased borrowing capacity.

Lenders evaluate financial reports each quarter to ensure the borrower's reported performance falls within the covenant threshold. When debt covenants are violated, lenders typically have the right to demand immediate repayment of the loan's outstanding balance (Nini et al., 2007). However, lenders rarely call the loan's outstanding balance due. Instead, lenders usually renegotiate covenant thresholds and loan terms with the borrower. These negotiations often result in costly concessions from the borrower (Beneish and Press, 1993; Nini et al, 2007). For example, lenders may restrict future capital expenditures (Roberts and Sufi, 2007a), limit merger and acquisition activity, or require changes in senior management (Baird and Rasmussen, 2006). In addition, lenders 
may restrict unused lines of credit, impose fines and fees, increase interest rates, or require additional collateral (Nini et al., 2007; Smith and Warner, 1978).

Just how costly covenant violation is to the firm is an unanswered empirical question. Some have argued that the costs of violating private debt covenants are relatively low. These arguments are based on the frequency of observed debt covenant violations in private credit agreements. For example, Dichev and Skinner (2002) find that $30 \%$ of firms in their sample report financial results outside the bounds of the covenant threshold. They argue that if so many firms violate covenants, the costs of renegotiating the covenants or obtaining waivers from the lender must be relatively low. Consistent with this argument, Duke and Hunt (1990) suggest that obtaining a waiver of the debt covenant violation may be "as simple as making a phone call to the bank."

Nini et al. (2007) also document a high frequency of debt covenant violation, providing evidence that $25 \%$ of all public firms reported at least one covenant violation between 1996 and 2005. ${ }^{1} \quad$ However, they document a variety of penalties imposed on violating firms in exchange for covenant waivers. They suggest that these penalties, which include reduced borrowing capacity, increased interest costs, capital expenditure restrictions, and fees and penalties, are costly. Although Nini et al. (2007) document the frequency of various outcomes of debt covenant violation, they do not provide estimates of the costs associated with these outcomes. Thus, while there is some evidence that debt

\footnotetext{
${ }^{1}$ This figure likely understates the actual incidence of debt covenant violation because firms are not required to report debt covenant violations unless they are material and are unresolved when financial statements are issued.
} 
covenant violation has associated costs, the magnitude of these costs remains an empirical question that has received sparse large sample testing. ${ }^{2}$

If covenant violation is indeed costly, firms will have incentives to avoid reporting financial results outside the covenant threshold. If incentives are strong enough, firms may use the latitude inherent in financial accounting rules to achieve the desired reported outcome (e.g., Press and Weintrop, 1990; Healy and Palepu, 1990). The debt covenant hypothesis (Watts and Zimmerman, 1986) predicts that firms will choose accounting methods that decrease the likelihood of debt covenant violation. For example, Beatty and Weber (2003) test whether firms with debt covenants are more likely to make income-increasing voluntary accounting changes than firms without debt covenants. ${ }^{3}$ They find that firms with debt covenants are indeed more likely to adopt incomeincreasing accounting policies than their non-covenant counterparts.

A similar line of research asks whether financial reporting pressure from debt covenants increases earnings management (without explicitly causing firms to change accounting methods). For example, Defond and Jiambalvo (1994) and Sweeney (1994) identify ex-post firms that have violated debt covenants. They then test whether discretionary accruals increase as firms approach technical default. Consistent with their

\footnotetext{
${ }^{2}$ Beneish and Press (1995) examine the market reaction to public disclosure of debt covenant violation. Nevertheless, their study is limited to a small sample of firms that actually reported covenant violations, so it is likely restricted to severe cases of debt covenant violation.

${ }^{3}$ Beatty and Weber (2003) also examine performance pricing provisions.
} 
hypotheses, both studies find that discretionary accruals increase as firms approach technical default. ${ }^{4}$

Dichev and Skinner (2002) study a large sample of firms with privately held loan contracts containing debt covenants. They test whether realizations of financial ratios restricted by financial covenants appear to be random, or whether they appear to be opportunistically reported. They conclude that the distribution of financial ratios does not appear to be random. Their results suggest that firms make accounting or investment choices that help them avoid covenant violation.

While several studies have examined the influence of debt covenants on earnings management, none has explicitly considered associated costs of earnings management in the context of debt covenants. These costs are important to consider because firms will only be tempted to manage earnings if the cost of managing earnings is less than the cost of violating debt covenants. Managing earnings may have a variety of costly consequences, including sacrificing real economic value for accounting earnings (Graham, Harvey, and Rajgopal, 2005; Roychowdhury, 2006; Wang and D’Souza, 2006), increasing regulatory scrutiny (Dechow et al., 1996; Liu and Ryan, 2006), increasing the likelihood of accounting restatements (Palmrose et al., 2004), and increasing the likelihood of shareholder litigation (Bonner et al., 1998; Skinner, 1997). In addition, if taxable income is increasing in accounting earnings, firms may incur tax costs when managing earnings.

\footnotetext{
${ }^{4}$ Gramlich, McAnally, and Thomas (2000), and Gramlich, Mayew, and McAnally (2006) show that firms also use discretion to manage balance sheet accounts to improve financial ratios related to debt covenants.
} 
The next sections more fully develop the possibility of an association between earnings management and tax expense. I focus on the association between earnings management and tax expense because tax expense is an observable cost. Calculating the amount of incremental tax expense firms are willing to incur to avoid crossing debt covenant thresholds will provide a lower-bound estimate of the cost of debt covenant violation. That is, while increased tax expense in just one possible cost of managing earnings, and managing earnings is just one costly behavior firms may engage in to avoid debt covenant violation, firms are not expected to manage earnings to a point where the increased tax expense is greater than the cost of violating a debt covenant. Thus, my calculations should be, on average, smaller than the actual cost of debt covenant violation.

\subsection{Financial reporting costs and book-tax trade-offs}

The financial reporting costs created by debt covenants may drive firms to make income-increasing accounting or investing choices. While firms prefer to increase accounting income without increasing taxable income (Badertscher et al, 2006; Badertscher et al, 2007), tax rules often prevent the simultaneous satisfaction of both financial reporting incentives and tax incentives. In these situations firms will be forced to trade the benefits of satisfying one incentive against the costs of failing to satisfy the other incentive.

Examples of firms incurring real economic tax costs to achieve a desired financial reporting treatment have been documented by Erickson, Hanlon, and Maydew (2004), Robinson (2007), Maydew, Schipper, and Vincent (1999), Engel, Erickson, and Maydew 
(1999), and others. ${ }^{5}$ Using a sample of firms accused of accounting fraud by the SEC, Erickson et al. (2004) show that firms are willing to pay $\$ 0.11$ to the IRS in tax for every $\$ 1.00$ of fraudulent earnings. Robinson (2007) shows that firms are willing to pay more for tax credits that increase pre-tax income than similar credits that increase after-tax income, even though the net income effect is equal for both. Maydew et al. (1999) find that managers are willing to incur avoidable tax costs to gain earnings and cash flow benefits in a setting examining spin-offs and divestitures, while Engel et al. (1999) show that firms are willing to sacrifice real economic gains to improve debt-to-assets ratios.

In addition, Cloyd, Pratt, and Stock (1996) and Mills and Newberry (2001) study whether managers are more willing to incur tax costs as financial reporting pressure increases. Both studies compare private firms to public firms under the assumption that financial reporting pressure is greater for public firms. The results from both studies are consistent with private firms being more willing than public firms to take aggressive tax positions even if the tax position will result in lower reported accounting income.

These studies suggest that as taxes and financial reporting interact, financial reporting pressure changes. When financial reporting pressure is high, firms will be unwilling to reduce accounting income even if it could result in tax savings. On the other hand, firms will be willing to increase accounting income even if it could result in tax costs. That is, when financial reporting pressure is high, firms are more likely to forgo tax-saving transactions or accounting choices in favor of income-increasing transactions or accounting choices. If the cost of debt covenant violation exceeds the cost of greater

\footnotetext{
${ }^{5}$ See Shackelford and Shevlin (2001) for a review of research that examines the trade-off between financial reporting incentives and tax incentives.
} 
taxes from increasing reported income, debt covenants may increase the tax burden firms bear, relative to what they would bear absent debt covenants. This leads to my hypothesis, stated in alternative form:

$\mathrm{H}_{\mathrm{A}}$ : There is a positive relation between financial reporting pressure induced by debt covenants and the firm's incremental tax burden.

That is, I hypothesize that managing earnings to avoid debt covenant thresholds induces firms to incur greater tax costs than they would if they did not have debt covenants.

\section{Sample Selection and Descriptive Statistics}

The sample selection begins with debt covenant data from the Dealscan database provided by Loan Pricing Corporation, and financial statement data from Compustat, provided by Standard \& Poor's. The Dealscan database consists of private credit agreements obtained from SEC filings and sources that Loan Pricing Corporation has developed directly with lenders. The database contains information on interest rates, financial covenants, performance pricing grids, lenders, and loan maturities for both individual loans and groups of loans called packages or deals.

Table 1 describes the sample selection. Firms are selected from the Compustat quarterly files covering the sample period 1994 to 2006 . Each firm-quarter is required to have non-missing values of the following variables:

1) Working capital accruals $(d W C)$ calculated as ( $\Delta$ data40- $\Delta$ data36)-( $\Delta$ data49$\Delta$ data47- $\Delta$ data45). Missing values of taxes payable (data47) are set to zero; ${ }^{6}$

2) Gross property, plant and equipment (GPPE) (data118);

\footnotetext{
${ }^{6}$ I remove taxes payable from working capital accruals to ensure that the incremental tax effect I capture is indeed related to the management of accruals, and not simply a spurious change in the firm's tax liability.
} 
3) Net property, plant and equipment (PPE) (data42);

4) Change in sales less the change in receivables ( $\Delta$ data2- $\Delta$ data37);

5) Pre-tax income (PTBI) (data23);

6) Current and lagged total assets (data44);

7) Market to book ratio $(M B)(($ data14*data61)/data60).

Firms are also required to have current tax expense (data63+data64) from the Compustat annual files. $^{7}$

These data requirements result in the selection of 5,082 firms corresponding to 96,499 firm-quarters. I match these firms to the Dealscan data using name and ticker symbol. Of the 5,082 Compustat firms, 1,775 have at least one deal recorded in Dealscan with at least one financial statement-based covenant, reducing the sample to 51,795 firmquarters. Of the 51,795 firm-quarters , 35,596 correspond to quarters when a loan is outstanding according to the deal effective dates reported in Dealscan. Finally, for most of my tests I require an estimate of debt covenant slack (SLACK). Data requirements to compute SLACK (described later) reduce the sample to 1,186 firms, corresponding to 16,651 firm-quarters. Many firms engaged in multiple deals. ${ }^{8}$ Thus, the $1,775(1,186)$ firms are represented by $4,038(2,096)$ deals in Dealscan.

Table 2 presents some of the basic characteristics of the debt contracts in my sample. The mean firm in my sample has 2.27 private debt deals on Dealscan. The mean (median) deal is $\$ 342.30$ ( $\$ 115$ ) million. An alternative measure is to scale the

\footnotetext{
${ }^{7}$ I use the Compustat annual files for this data because current tax expense is not available in the quarterly files. If data63 or data64 is missing, I use (data16-data50) as a measure of current tax expense.

${ }^{8}$ The most primitive unit of observation in Dealscan is a "facility" which is an individual loan. I refer to groups of loans initiated at the same time and packaged together with a common set of covenants as "deals".
} 
deal size by total assets. The mean deal is $31 \%$ of total assets, with the median deal $24 \%$ of total assets. It should be noted that many of the deals captured in Dealscan are lines of credit that are not completely drawn down. Thus, the actual mean (median) liability is likely to be less than the $31 \%$ (24\%) of assets reported in Table 2.

On average, deals mature in 16 quarters. However, deal terms may be renegotiated upon covenant violation. Dichev and Skinner (2002) report that debt covenants do not appear to be binding after the first violation. Therefore, I calculate an alternative length of maturity as an estimate of the length of time the covenant recorded in Dealscan is binding. Using estimates of covenant violation (described below), I estimate that the average deal is no longer effective as recorded in Dealscan after eight quarters. The average spread over LIBOR is 172 basis points, with the median spread over LIBOR coming in at 150 basis points. ${ }^{9}$

Among firms with at least one financial covenant, $62 \%$ of deals have at least one financial statement-based performance pricing provision. The average firm has 2.96 financial covenants. Table 3 , shows the frequency and types of financial covenants. The most common financial covenants are debt to earnings before interest, taxes, depreciation, and amortization (EBITDA) (45\% of deals), fixed charge coverage (37\% of deals), and interest coverage (33\% of deals). The least common financial covenants are cash interest coverage (1\% of deals), senior leverage (less than 1\%) and loan to value (less than 1\%).

\footnotetext{
${ }^{9}$ Most deals in Dealscan show rate spreads over LIBOR, while a few report spreads over the prime rate. The distinction is not important in this study.
} 


\section{Empirical Design}

As stated earlier, the objectives of this paper are to test whether firms incur tax costs incremental to what they would have incurred absent the financial reporting pressure from debt covenants, and to quantify the incremental costs. Recall from the hypothesis developed above that I expect a positive relation between financial reporting pressure induced by debt covenants and incremental tax expense. The hypothesized relation between incremental tax expense and debt covenants can be written as:

$$
\text { ITAX }=\alpha_{0}+\alpha_{1} \text { Debt Covenant Pressure }+\sum_{k} \gamma_{k} \text { CONTROL }_{k}+\varepsilon,
$$

where ITAX is incremental tax expense (defined below). The hypothesis predicts $\alpha_{1}$ to be positive.

Estimation of Eq. (1) requires empirical proxies for incremental tax expense, financial reporting pressure from debt covenants, and control variables. In section 4.1 I develop a proxy for incremental tax. In section 4.2 I develop a proxy for debt covenant pressure. In section 4.3 I identify control variables and explain how they are empirically measured.

\subsection{Measuring incremental tax expense}

I estimate the incremental tax cost firms bear in three steps. First, I develop a measure of discretionary income using the method developed in Jones (1991). ${ }^{10}$ Second, I estimate the rate at which discretionary income maps into taxable income. Third, I use the results from the first two steps and a proxy for the firm's marginal tax rate to estimate the taxes firms pay on discretionary income. I call this variable ITAX for incremental tax expense.

\footnotetext{
${ }^{10}$ By using the Jones (1991) model in this setting to compute discretionary income I assume that firms have no discretion in cash flows, that the predicted component of total accruals is likewise nondiscretionary, and the residual component of accruals is discretionary
} 


\subsubsection{Estimating discretionary income}

A large body of research tests whether firms report opportunistic financial outcomes. Most of this work requires researchers to estimate discretionary income. Studies by Jones (1991), Dechow, Sloan and Sweeney (1995) and Kothari, Leone, and Wasley (2005) are prominent in this literature. Jones (1991) estimates discretionary income by regressing total accruals on the firm's property, plant and equipment and the change in the firm's sales. The intuition underlying the Jones (1991) model is that these factors will capture the economic forces driving nondiscretionary accruals. The residual from this regression is then considered to be the portion of income that is not driven by economic fundamentals, but rather by managerial discretion in accounting choices or accrual estimation. Dechow et al. (1995) test the empirical validity of the Jones (1991) measure of discretionary accruals. They find that a modified model produces more powerful results than the original model, but argue that neither model is particularly powerful. Kothari et al. (2005) suggest that adjusting discretionary accrual measures for economic performance increases its empirical validity.

I use a variant of the model in Jones (1991) to estimate discretionary income. Following prior research (Bartov, Gul, and Tsui, 2000; Balsam, Bartov, and Marquardt, 2002; Louis and Robinson, 2005; Teoh, Welch, and Wong, 1998), I estimate the regression shown below for each two-digit SIC code and year:

$$
d W C_{i t}=\sum_{k=1}^{4} \theta_{k} Q T R_{k}+\theta_{5} G P P E_{i t}+\theta_{6} d S A L E S_{i t}+\theta_{7} P T B I_{i t}+u_{i t}
$$

where $Q T R_{k}$ is a separate intercept for each fiscal quarter, $d W C$ is working capital accruals, GPPE is gross property, plant and equipment, $d S A L E S$ is the change in sales less the change in accounts receivable, and PTBI is pre-tax book income. All variables 
(including the four separate intercepts) are scaled by total assets at the beginning of the period. I use working capital accruals instead of total accruals as the dependent variable because nearly all income statement-based financial covenants are written on earnings before depreciation. In terms of avoiding the costs associated with debt covenant violation, firms gain little, or perhaps nothing at all, by managing earnings after depreciation. Therefore, including depreciation or other long-term accruals in the dependent variable may add noise to the error term and diminish the validity of estimated discretionary income for purposes of this study. Second, I include pre-tax book income as a control for performance (Kothari et al., 2005). The empirical estimate of the error term from this regression, $\hat{u}_{i t}$, is used as a measure of discretionary income for each firm $i$ at time $t$. I call this measure $D A C C$.

\subsubsection{Estimating the rate at which financial income maps into taxable income}

Taxes are not necessarily paid on all earnings recognized in the financial statements. Establishing the relation between accounting income and taxable income is the next step in calculating a proxy for incremental tax expense. For purposes of this study, the relation between pre-tax book income $(P T B I)$ and taxable income $\left(T I^{*}\right)$ is defined as:

$$
T I^{*}=\gamma P T B I,
$$

where $\gamma$ captures the rate at which current PTBI maps into $T I^{*}$. Prior research suggests that the rate of conformity may differ systematically across firms with and without financial reporting pressure from debt covenants (Cloyd et al., 1996; Mills and Newberry, 2001). In the notation of Eq. (3) this can be written as:

$$
\gamma=\varphi_{1}+\varphi_{2} \text { COVFIRM, }
$$


where COVFIRM is an indicator variable equal to one if the firms has debt covenants, zero otherwise.

Substituting Eq. (4) into Eq. (3) yields the following:

$$
T I^{*}=\varphi_{1} P T B I+\varphi_{2} P T B I * C O V F I R M .
$$

Taxable income $\left(T I^{*}\right)$ is not observable in financial statement data and is therefore measured with error from publicly available disclosures (Hanlon, 2003). This can be written as:

$$
T I=T I^{*}+e,
$$

where $T I$ is the empirical proxy for true taxable income, $T I^{*}$, and $e$ is measurement error.

Substituting Eq. (6) into Eq. (5) gives the following expression:

$$
T I=\alpha_{0}+\varphi_{1} P T B I+\varphi_{2} P T B I * C O V F I R M+\varepsilon,
$$

where $\alpha_{0}$ captures the mean of the measurement error $e$, and $\varepsilon$ captures the random variation in $e$.

It is possible that the rate of conformity differs for non-discretionary income and discretionary accruals. To allow for this possibility, I modify Eq. (7) as follows:

$$
\begin{aligned}
T I= & \alpha_{0}+\omega_{1}(P T B I-D A C C)+\omega_{2} D A C C+\omega_{3}(P T B I-D A C C) \cdot C O V F I R M+ \\
& \omega_{4} D A C C \cdot \text { COVFIRM }+\varepsilon,
\end{aligned}
$$

where $(P T B I-D A C C)$ is non-discretionary income, DACC is discretionary accruals and COVFIRM is an indicator equal to one if the firm has a covenant outstanding during the year, zero otherwise.

The empirical estimation of Eq. (8) is implemented with annual data because information to calculate taxable income $(T I)$ is not available quarterly. I sum the four 
quarters of discretionary accruals $(D A C C)$ estimated earlier to obtain an estimate of annual discretionary accruals.

The estimated coefficient $\widehat{\omega}_{2}$ captures the rate of conformity between discretionary income and taxable income for firms without debt covenants. Likewise the sum of the estimated coefficients, $\widehat{\omega}_{2}+\widehat{\omega}_{4}$, captures the rate of conformity between discretionary income and taxable income for firms with debt covenants.

Eq. (8) has been developed without regard to a variety of firm-specific control variables that could be correlated with book-tax conformity. This is because the goal of Eq. (8) is not to explain book-tax conformity. Rather, the purpose of Eq. (8) is to develop an estimate of the rate of book-tax conformity for firms with and without debt covenants. Controlling for firm-specific factors that could influence the rate of book-tax conformity will be addressed in section 4.3 below.

\subsubsection{Calculating incremental tax.}

Having now estimated discretionary income for each firm, and having an estimate of book-tax conformity for discretionary income, I can estimate the primary variable of interest, incremental tax expense as

$$
\operatorname{ITAX} X_{i}=\left[D A C C_{i} \cdot \widehat{\omega}_{2}\right] \cdot \tau_{i},
$$

for firms without covenants, and

$$
\operatorname{ITAX} X_{i}=\left[D A C C_{i} \cdot\left(\widehat{\omega}_{2}+\widehat{\omega}_{4}\right)\right] \cdot \tau_{i}
$$

for firms with covenants. The parameter $\tau_{i}$ is the marginal tax rate from Graham (1996) for firm $i .^{11}$

\subsection{Measuring reporting pressure from debt covenants.}

\footnotetext{
${ }^{11}$ Marginal tax rates are available upon request from John Graham for academic research purposes. If the firm's marginal tax rate is missing from the file received from John Graham, I assume that its marginal tax rate is the top statutory tax rate (usually $35 \%$ during my sample period).
} 
Measuring financial reporting pressure from debt covenants is the second empirical challenge I face. Debt covenant slack is not reported in public filings with the Securities and Exchange Commission. However, recent research has begun to identify and evaluate loan covenants using data provided by Loan Pricing Corporation in the database Dealscan (e.g., Dichev and Skinner, 2002).

My first measure of financial reporting pressure from debt covenants is covenant slack $(S L A C K)$. I measure covenant slack using quarterly Compustat data for each firm with at least one of the following financial statement covenants: current ratio, interest coverage, quick ratio, EBITDA, debt to EBITDA, debt to equity, debt to tangible net worth, leverage, tangible net worth, and net worth. Firms that do not have one of these covenants are not given a value of $S L A C K$, and are excluded from analyses that use $S L A C K$. For each covenant I measure $S L A C K$ as the actual value of the covenant estimated using Compustat quarterly data less the covenant threshold from Dealscan, the difference scaled by the standard deviation of the actual value over the previous eight quarters. Because measuring debt covenant slack is noisy (Dichev and Skinner, 2002), I rank these values into deciles for each covenant. In spite of difficulties in estimating covenant slack, I expect that, on average, the slack variable will be correlated with the firm's actual debt covenant slack. Excessive noise in the empirical estimate of SLACK will bias against finding results.

As a robustness check, I measure reporting pressure from debt covenants as an indicator variable that is equal to one of the firm has debt covenants and zero otherwise. This method allows for a much larger sample, but does not facilitate comparison of firms with tight covenants to firms with loose covenants. 


\subsection{Identifying and measuring control variables}

As noted earlier, incremental tax expense (ITAX) could be influenced by a variety of firm-specific factors. These factors may influence ITAX via discretionary accruals estimates, or via the rate of book-tax conformity. I therefore identify and control for several factors.

First, I control for observations that have negative pre-tax accounting income. Estimating taxable income from financial statements can be problematic for loss firms because losses and gains are treated asymmetrically for tax purposes. Although I attempt to control for this issue by subtracting the change in the firm's net operating loss carryforward balance from grossed up current tax expense when calculating taxable income, this fix may not be perfect. For example, Mills et al. (2003) document reliability problems with the Compustat net operating loss variable. Thus, I include a variable $(N E G)$ that equals one if the firm has a pre-tax accounting loss, and zero otherwise.

Second, I control for net operating loss carryforwards (NOL) by including an indicator variable that is equal to one if Compustat reports a net operating loss balance at the end of the year, zero otherwise. I include this variable to control for the possibility that firms with NOL carryforwards can manage earnings without incurring incremental tax expense.

Third, I control for capital intensity by including gross property, plant and equipment $(P P \& E)$. I include this variable to help control for cross-sectional differences in business models that could change a firm's ability or propensity to engage in earnings 
management. In addition, firms with greater capital intensity may have a different propensity to borrow funds and/or agree to debt covenants in private credit agreements.

Fourth, I control for the ratio of intangible assets to total assets, INTANG. Firms with intangible assets may be more capable of shifting income to low-tax jurisdictions than firms with tangible assets. For example, a recent Wall Street Journal article highlighted a tax avoidance technique used by Merck to shift income from the patents related to the drug Zocor to a subsidiary in Bermuda, thereby avoiding taxes. ${ }^{12}$ In addition, firms with a high proportion of intangible assets may have a lower ability to obtain debt financing because they may have fewer tangible assets to pledge as collateral.

Fifth, I include an indicator variable for whether or not the firm reports foreign pre-tax income (FOPS). Foreign operations may change book-tax conformity because the company is operating in a variety of different tax jurisdictions. Multinational firms may have more opportunities to shift income to avoid taxes (Rego, 2003).

Sixth, I control for firm size (SIZE), measured as the natural log of total assets. Firm size may be important in explaining book-tax differences because it may act as a proxy for tax planning ability, the ability to shift income among various subsidiaries within the corporate structure, or financial sophistication. However, the empirical findings on the relation between firm size and various tax characteristics have been mixed (Zimmerman, 1983; Rego, 2003). Firm size has also been shown to correlate with discretionary accruals (Kothari et al. 2005; Kim et al., 2003).

Seventh, I control for the market to book ratio $(M B)$, measured as the market value of equity to the book value of equity at the fiscal quarter end. The market to book

\footnotetext{
${ }^{12}$ Drucker, Jesse. 2006. "Bermuda Triangle: How Merck Saved \$1.5 Billion Paying Itself for Drug Patents." The Wall Street Journal:A1.
} 
ratio may be associated with growth opportunities that could affect the firm's propensity to borrow. It could also reflect intangible assets that may not be reflected on the firm's balance sheet but are priced.

Eighth, I control for industry effects by including an indicator variable for each two-digit SIC code (INDUSTRY). Book-tax differences may vary by industry because of different asset compositions across industries, and different accounting conventions common within a given industry. Some tax rules and accounting conventions are industry-specific (Plesko, 2007). Earnings management may also vary across industries.

Finally, I control for time effects by including an indicator variable for each quarter $(T I M E)$. Book-tax conformity may vary over time as statutory differences between accounting income and taxable income change.

Including these variables as controls results in the following regression:

$$
\begin{aligned}
& I T A X_{i t}=\alpha_{0}+\alpha_{1} S L A C K_{i t}+\gamma_{1} N E G_{i t}+\gamma_{2} N O L_{i t}+\gamma_{3} P P \& E_{i t}+ \\
& \gamma_{4} I N T A N G_{i t}+\gamma_{5} \text {FOPS }_{i t}+\gamma_{6} S I Z E_{i t}+\gamma_{7} M B_{i t}+ \\
& \sum_{j} \gamma_{j} \operatorname{INDUSTRY_{j}}+\sum_{k} \gamma_{k} \operatorname{TIME}_{k}+\varepsilon_{i t}
\end{aligned}
$$

where all variables are as previously defined. Based on my hypothesis above, I expect a negative relation between SLACK and ITAX $\left(\alpha_{1}<0\right)$. That is, as debt covenant slack tightens (becomes smaller), incremental tax expense will increase.

The model in Eq. (10) forces the relation between incremental tax and debt covenant slack to be linear. I relax this assumption by allowing $S L A C K$ to be piecewise non-linear as follows: 


$$
\begin{aligned}
\operatorname{ITAX}_{i t}= & \beta_{0}+\beta_{1} \text { TIGHTSLACK }_{i t}+\beta_{2} \text { MIDSLACK }_{i t}+\gamma_{1} N E G_{i t}+ \\
& \gamma_{2} \text { NOL }_{i t}+\gamma_{3} \text { PP\&E } E_{i t}+\gamma_{4} \text { INTANG }_{i t}+\gamma_{5} \text { FOPS }_{i t}+\gamma_{6} \text { SIZE }_{i t}+ \\
& \gamma_{7} \text { MB }_{i t}+\sum_{j} \gamma_{j} I N D U S T R Y_{j}+\sum_{k} \gamma_{k} \text { TIME }_{k}+\varepsilon_{i t} .
\end{aligned}
$$

In this specification, firm-quarters falling in the loosest three groups of the SLACK distribution serve as the baseline group (captured by the intercept). TIGHTSLACK captures firm-quarters in the tightest three groups of the distribution, and MIDSLACK captures firm-quarters in the middle four groups of the distribution. The hypothesis predicts that $\beta_{1}$ will be positive, and that $\beta_{2}$ will be positive, but less than $\beta_{1}$.

\section{Results}

In this section I first present descriptive statistics and results from the book-tax conformity model. I then present results from the tests of my hypothesis. Finally, I calibrate the economic magnitude of the results.

\subsection{Book-tax conformity models}

Descriptive statistics on variables used to estimate the rate of conformity between book and taxable income are presented in Table 4. Recall that this portion of the analysis (Table 4 only) uses firm-years (as opposed to firm-quarters in the remainder of the analysis) because data limitations preclude the calculation of taxable income with quarterly periodicity. Panel A shows descriptive statistics for firm-years associated with firms that have a covenant outstanding. Panel B shows descriptive statistics for firm-

years that do not have a debt covenant. Panel $\mathrm{C}$ reports the estimation of the conformity regressions suggested by Eq. (7) and Eq. (8).

Panels A and B suggest that firms with debt covenants are more profitable, have higher taxable income, and have higher discretionary accruals than firms without debt 
covenants. These facts suggest the need to allow the conformity coefficients estimated in Table 4, Panel $\mathrm{C}$ to vary depending on whether the firm has debt covenants.

Table 4, Panel C presents the results of the book-tax conformity regressions suggested by Eq. (8) and Eq. (9). The first model suggests that, on average, $\$ 0.83$ per dollar of pre-tax accounting income is recognized as taxable income for firms without debt covenants, while $\$ 0.78$ per dollar of pre-tax accounting income is recognized as taxable income for firm with debt covenants. In Model 2, I allow the coefficient to vary for non-discretionary and discretionary income. I find that the rate of conformity for discretionary accruals is not statistically different from non-discretionary accruals. Consistent with prior research (Cloyd et al 1996; Mills and Newberry, 2001), I find that firms with financial reporting pressure from debt covenants have lower book-tax conformity than firms without financial reporting pressure from debt covenants. In fact, firms with debt covenants have about $\$ 0.07$ cents less per dollar map into taxable income than their non-covenant counterparts. However, the result does not hold for the discretionary portion of income. Covenant firms appear to have slightly higher book-tax conformity for the discretionary portion of income, but this result is not statistically significant.

These results are generally consistent with the incentives facing firms with covenants. Firms with covenants will be less willing to engage in conforming transactions that reduce taxable income because they may also reduce book income, resulting in lower book-tax conformity. On the other hand, covenant firms may be more willing to engage in income-increasing discretionary actions, in spite of the fact that they 
may increase taxable income. Empirically, there is no difference between the conformity of discretionary accruals for covenant firms and non-covenant firms.

\subsection{Incremental tax and financial reporting pressure}

Table 5, Panels A and B present descriptive statistics of the variables used in the tests of my hypothesis. Of primary interest is the incremental tax variable, ITAX. Recall from section 4.3 that ITAX is calculated using discretionary income and book-tax conformity results. Univariate statistics suggest that the mean ITAX is greater for firms with debt covenants $(0.03 \%$ of beginning assets $)$ than it is for firms without debt covenants $(-0.02 \%$ of beginning assets).

Table 5, Panel A also shows descriptive statistics for the estimate of debt covenant slack, SLACK. SLACK is a discrete variable, ranging in value from zero to nine. Firms with the tightest debt covenant slack (with the most financial reporting pressure) have low values of SLACK. The mean (median) firm has a value of SLACK of 3.98 (4.00). While SLACK is based on decile rankings of each covenant's slack compared to other values of slack for the same covenant, the mean of SLACK varies from the value of 4.50 that would be expected from a true decile ranking. This happens because some firms have more than one covenant during a given quarter, and I use the tightest value of $S L A C K$ for a firm during each quarter, skewing the distribution slightly toward tighter covenants. Thus, the 10 SLACK groups do not each contain exactly $10 \%$ of the sample

Table 5 also presents descriptive statistics for the control variables used in the regressions. Panel A reveals that $15 \%$ of firms with debt covenants have negative annual earnings. This number jumps to about $35 \%$ for non-covenant firms in Panel B. 
Consistent with earlier findings that covenant firms appear to be more profitable, Panel A reveals that covenant firms have lower net operating loss carryforwards than their noncovenant counterparts in Panel B. Not surprisingly, covenant firms also have more longterm debt (27\% of assets) than non-covenant firms (19\% of total assets). In fact, covenant firms appear to be different from non-covenant firms on just about every dimension reported. Because of this, most of my empirical tests are estimated within the cross-section of firms with debt covenants.

Table 6 reports the results of fitting the regression suggested by Eq. (10). These results are a direct test of the main hypothesis. Models 1-3 are estimated only using firms with debt covenants and values of SLACK. All coefficients (and standard errors) are multiplied by 100 to aid in presentation of the results. Recall from the hypothesis section that I expect incremental tax expense to be increasing in debt covenant pressure. Because debt covenant pressure is decreasing in $S L A C K$, I expect to find that the coefficient on SLACK is negative. Consistent with this prediction, the coefficient is negative and significant across all variations in the model. In Model 1, I estimate Eq. (10) excluding controls. In Model 2, I estimate Eq. (10) controlling for firm-specific factors, but excluding industry and time fixed effects. Finally, in Model 3 I estimate Eq. (10) as it is specified, including both firm-specific controls and industry and time fixed effects. While the economic magnitude of the coefficient on $S L A C K$ is examined in detail in section 5.3 below, the results suggest that tightening debt covenant slack by one decile increases the firm's incremental tax expense per quarter by $0.02 \%$ of total assets, controlling for other factors that may influence the incremental tax measure. Standard errors are clustered by firm and time (Petersen, 2007). 
In Model 4 of Table 6 I estimate the model suggested by Eq. (10), except I include firms that do not have debt covenants, and substitute an indicator variable, COVFIRM, for SLACK. The indicator variable COVFIRM is equal to one if the firm has debt covenants and zero otherwise. I predict a positive coefficient on COVFIRM because firms with covenants are predicted to have more financial reporting pressure than firms without covenants. I find results consistent with the prediction. The coefficient suggests that incremental tax expense is $0.06 \%$ of assets per quarter higher for firms with covenants than for firms without covenants. This magnitude would be equivalent to a three decile tightening of SLACK based on the results presented for Model 3.

The analysis in Table 6, Models 1-3, based on Eq. (10), forces the relation between incremental tax and $S L A C K$ to be linear. The model suggested by Eq. (11) relaxes this assumption by creating indicator variables for the tightest three SLACK groups, called TIGHTSLACK, and the middle four SLACK groups, called MIDSLACK. The loosest three SLACK groups are captured by the intercept.

Table 7 presents the results from this modified specification. Again, all coefficients are multiplied by 100 to facilitate presentation. In Model 1 I estimate the regression without any control variables. Model 2 includes firm-specific control variables, while Model 3 includes the firm-specific controls, and industry and time fixed effects. While the economic magnitude of these results will be explored in detail in section 5.3 below, an initial examination of the results suggests that firms with debt covenant slack in the tightest three groups (TIGHTSLACK) incur $0.08 \%$ of total assets more tax expense per quarter than firms with debt covenant slack in the loosest three 
groups. Firms in the middle four groups (MIDSLACK) of debt covenant slack are no different statistically than firms in the tightest three groups of debt covenant slack. ${ }^{13}$

To graphically illustrate the relation between debt covenant slack and incremental tax expense, I further loosen the restrictions on the model suggested by Eq. (11) and allow each SLACK group to have its own coefficient. A graphical illustration of this result is presented in Figure 1. The figure plots incremental tax on the $\mathrm{Y}$ axis against SLACK on the $\mathrm{X}$ axis. I find that the $1^{\text {st }}, 2^{\text {nd }}$, and $4^{\text {th }}$ groups are statistically different from firms without debt covenants (represented by white markers in the figure). The figure shows a generally downward-sloping trend. Most of the incremental tax appears to be paid by firms in the tightest four groups of the SLACK distribution, while the loosest six groups are relatively flat.

\subsection{Economic magnitude of incremental tax expense}

I calculate the economic magnitude of the results in Table 8, and compare the results to various benchmarks in Table 9. Because accruals management is akin to borrowing earnings from the future, any incremental tax paid is assumed to be the acceleration of tax expense, not the creation of new tax expense. I assume that by accelerating tax each quarter for $t$ quarters, the firm is foregoing the opportunity to make one lump sum payment in quarter $t+1$. Thus, the cost to the firm is in the time value of money resulting from accelerated tax payments. For example, suppose the effective life of the loan is eight quarters. The firm could choose to pay $\$ 1.00$ each quarter for eight quarters, or a lump sum of $\$ 8.00$ in the ninth quarter. In this example, and assuming a 2.5\% quarterly interest rate, the value lost because of tax payment acceleration would be

\footnotetext{
${ }^{13}$ In unreported results, I include all firms that do not have debt covenants. I find that the firms in the tightest group are statistically different from firms without debt covenants. I also find that firms in the middle and loose SLACK groups are statistically indistinguishable from firms without debt covenants.
} 
$\$ 0.76 .{ }^{14}$ In other words, the firm would lose $\$ 0.76$ over the life of the loan by paying $\$ 1.00$ each quarter instead of $\$ 8.00$ in the ninth quarter.

Table 8 illustrates the computation of the incremental tax costs firms incur in terms of basis points. In Line 1, I present the coefficient from Table 7, Model 3. This coefficient suggests that firms in the tightest three SLACK groups pay on average $0.08 \%$ of assets in incremental tax each period. Line 2 is a time value of money factor for each $\$ 1.00$ accelerated each quarter, assuming a $2.5 \%$ quarterly interest rate, and the mean (median) effective loan maturity from Table 2. Line 3 in Table 8 multiplies these two numbers to calculate the discounted tax cost over the life of the loan. Over the life of the average loan in the tightest three $S L A C K$ groups, a firm would expect to increase tax costs by $0.06 \%$ of total assets because of the acceleration of tax payments.

The economic significance of the tax cost is difficult to interpret without a reasonable benchmark. A natural benchmark is interest expense. In Line 4 of Table 8 I report the mean (median) interest expense (scaled by lagged total assets) for each firmquarter. I assume that the mean (median) firm pays this amount of interest each quarter. Using a $2.5 \%$ quarterly discount rate, I calculate the present value of all interest payments over the life of the mean (median) loan. The time value of money factor is presented in Line 5 for the mean (median) effective loan maturity. Line 6 shows that over the life of the loan, the mean (median) firm would pay $3.73 \%$ (2.52\%) of total assets in interest expense. Dividing the discounted tax cost of the loan by the discounted interest cost of the loan suggests that tax costs are $1.70 \%(1.52 \%)$ of interest costs at the mean (median). Empirically, the mean (median) firm appears to pay an interest rate of 761 (706) basis

\footnotetext{
${ }^{14}$ The calculation is: $\$ 1.00 \operatorname{PVA}(8,2.5 \%)-\$ 1.00 * t \operatorname{PV}(9,2.5 \%)$
} 
points. ${ }^{15}$ Thus, the tax cost is equivalent in size to paying 12.92 (10.72) additional basis points on its debt at the mean (median). This amount could be interpreted as a lower bound on the cost of covenant violation. The average firm appears to be willing to sacrifice an amount equal to 12.92 basis points of interest on its loans to avoid violating debt covenants.

In Table 9 I compare the results to several benchmarks. The first row in Panel A presents the tax cost of violation calculated in Table 8. In the next row, I compare the basis point calculation to the stated loan spread (usually the interest rate above LIBOR). I find that the mean (median) firm incurs tax costs equivalent to about $7.53 \%(7.14 \%)$ of its loan spread.

In the third row of Table 9, Panel A, I calculate how much incremental tax the firm pays for every $\$ 100$ of discretionary accruals. For this calculation I divide the present value of the tax cost by the present value of all discretionary accruals over the life of the loan. The numerator is obtained from Table 8, Line 3. The denominator is obtained by estimating the following model:

$$
\begin{aligned}
\text { DACC }_{i t}= & \beta_{0}+\beta_{1} \text { TIGHTSLACK }_{i t}+\beta_{2} \text { MIDSLACK }_{i t}+\gamma_{1} N E G_{i t}+ \\
& \gamma_{2} N O L_{i t}+\gamma_{3} P P \& E_{i t}+\gamma_{4} I N T A N G_{i t}+\gamma_{5} \text { FOPS }_{i t}+\gamma_{6} \text { SIZE }_{i t}+ \\
& \gamma_{7} M B_{i t}+\sum_{j} \gamma_{j} I N D U S T R Y_{j}+\sum_{k} \gamma_{k} T I M E_{k}+\varepsilon_{i t} .
\end{aligned}
$$

I use the coefficient on TIGHTSLACK as an estimate of the discretionary income of the average firm with tight slack. Assuming the firm accelerates this amount of income in each quarter for the life of the loan, I calculate the present value of discretionary accruals. I use this value for the denominator.

\footnotetext{
${ }^{15}$ I estimate the cost of debt by dividing the firm's interest expense by its long term debt and debt in current liabilities.
} 
I find that the average firm with $S L A C K$ in the tightest three groups pays $\$ 2.80$ for every $\$ 100$ of discretionary accruals. This result is approximately one-fourth as large as the $\$ 11.00$ in taxes paid per $\$ 100$ of allegedly fraudulent earnings documented by Erickson et al. (2004). However, the earnings management I document is likely to be much less severe than the alleged fraud studied by Erickson et al. (2004), so the lower tax cost is reasonable.

In Panels B and C of Table 9, I calculate the lower bound on covenant violation using two alternative methods. In Panel B I replace the value in Table 8, Line 1 with the coefficient on SLACK in Table 6, Model 3, and assume a five-decile shift in SLACK. That is, Panel B estimates the tax cost of a firm whose debt covenant SLACK is, on average, five deciles tighter than the baseline firm. The remaining computations are carried out as in Table 8. Results are similar to Panel A, although they are slightly larger.

In Panel C I use information for each firm to calculate a distribution of tax costs. That is, I substitute as much firm-specific information into Table 8 as possible when making the calculations. First, I compute each firm's average SLACK decile over the life of the loan. I then use a group-specific coefficient (from Figure 1) as that firm's average quarterly incremental tax expense (i.e. the average quarterly incremental tax expense for the SLACK group that the firm falls into over the life of the loan). Instead of using the mean (or median) effective time to maturity in calculating the value lost due to the time value of money, I use each loan's effective time to maturity. Instead of using the mean (median) interest expense as in Table 8, I use each firm's interest expense. Finally, instead of using the mean (median) cost of debt as in Line 8 of Table 8, I use each firm's estimated cost of debt. This procedure produces a unique tax cost for each firm. The 
first row of Table 9 Panel $\mathrm{C}$ presents the mean (median) of this distribution. While the distribution is slightly more skewed than that presented in Panel A, the magnitudes are quite similar at the median, but larger at the mean. Specifically, I find that the mean (median) firm is willing to pay the equivalent of 22.72 (10.78) basis points to avoid debt covenant violation. This translates to increasing the mean (median) loan spread by $21.41 \%(6.85 \%)$

These estimates of a lower-bound on the cost of debt covenant violation are much smaller than those estimated by Beniesh and Press (1995). They find that violation costs are around 3\% of market value of equity. My results suggest a much smaller cost, less than $1 \%$ of market value of equity. On the other hand, Beniesh and Press (1995) examine a small sample of relatively severe violation cases. I study a broad sample of firms, many of which have not violated debt covenants. Thus, the results in Beniesh and Press (1995) could be interpreted as an upper bound on the cost of debt covenant violation, while the results I present are better interpreted as a lower bound on the cost of debt covenant violation.

While the three methods used above to calculate the economic magnitude of the tax costs firms incur to avoid violation of debt covenants differ, all three methods suggest that firms face an economically meaningful tax cost because of the financial reporting pressure induced by debt covenants. Firms appear willing to increase tax costs to avoid debt covenant violation. If firms are behaving optimally, these costs are less than or equal to the expected costs of technical default, suggesting a lower bound on the cost of debt covenant violation. Alternatively, these costs could be thought of as an additional 
cost of borrowing that potentially offsets some portion of the tax benefits of debt from interest deductibility.

\subsection{Additional tests}

I develop several alternative tests. First, in Figure 2 I plot the evolution of incremental tax in event time surrounding each quarter the firm had a covenant in the tightest SLACK group. This figure shows that firms with debt covenants have much greater values of incremental tax leading up to quarters with tight debt covenants, but then incremental tax drops off substantially after the quarter in the tightest debt covenant group. This result is driven by a large number of firms that default during the quarter slack is in the tightest decile. This event time variation is consistent with the incremental tax being caused by debt covenants.

Second, I restrict the sample to firms that have positive annual earnings. I do this to mitigate concerns associated with calculating the rate of book-tax conformity when earnings are negative. Additionally, I do this to ensure that firms with negative earnings are not driving the differences in discretionary accrual estimates for firms with tight debt covenant slack. All results are statistically similar, and the economic magnitude of the results does not change substantially.

Third, I estimate the tests using annual data instead of quarterly data. While annual data is conducive to the calculation of book-tax conformity and discretionary accruals, the periodicity does not coincide with the frequency of loan covenant evaluation by lenders. Nevertheless, I assume that the firm's debt covenant slack for the year is the tightest value of slack reported during any quarter during the year and re-run the tests. All results are similar in terms of statistical significance and economic magnitude. 


\section{Conclusion and Possible Future Research}

This study tests the hypothesis that firms incur tax costs to avoid violation of debt covenants and estimates the magnitude of the tax costs firms are willing to incur. Firms incur additional tax costs as a result of income-increasing earnings management undertaken to avoid covenant violation. Results from a variety of tests suggest that the mean firm is willing to incur costs between $7.53 \%$ to $21.41 \%$ of the loan spread. This translates to an increase in borrowing costs of between 12.92 (10.72) and 22.72 (12.81) basis points for the mean (median) firm. As covenant slack tightens, estimated tax costs increase. Since firms are willing to incur these additional tax costs as a result of activities to avoid convent violation, the tax costs can be interpreted as a lower bound on the cost of debt covenant violation in private credit agreements.

As a byproduct of the analysis, I also show that the rate of conformity between financial income and taxable income decreases as debt covenant pressure increases. This result is consistent with findings in prior research that suggest private firms are more willing than public firms to take aggressive tax positions even if the tax position results in lower financial income (Cloyd et al., 1996; Mills and Newberry, 2002).

The findings in this study provide a basis for several research extensions. Some research suggests that debt covenants on loans with more lending participants will be more costly to renegotiate (Lee and Mullineaux, 2004). On the other hand, other research (Roberts and Sufi, 2007b) finds that the frequency of loan renegotiation does not vary with syndicate size. Thus, one empirical question that could be answered with an analysis that builds on this study is whether the expected costs of debt covenant violation vary with the structure of the loan. 
Similarly, some research suggests that firms and banks can reduce the costs of borrowing and lending by developing relationships over time (Boot, 2000). However, the effect of relationship banking on the cost of debt covenant violation remains an unanswered empirical question. The analysis in this paper could provide a platform for studying the influence of relationship lending on expected costs of debt covenant violation.

While prior research has examined why firms take on financial covenants (e.g., Demerjian, 2007; Bradley and Roberts, 2004), no research has examined why some covenants are set tighter than others. Using the measures of debt covenant slack computed in this study, one could study the characteristics of firms associated with the tightness of covenant slack at loan inception.

Finally, a substantial body of research in corporate finance examines whether firms have reached their "optimal" capital structure from a tax point of view (e.g., Miller and Modigliani, 1963; DeAngelo and Masulis, 1980; Miller, 1977). Several papers conclude that firms do not carry enough debt to take full advantage of corporate tax deductions on interest expense (e.g., Graham, 2000; Graham, Lang, and Shackelford, 2004). It is possible that underlevered firms could be prohibited by debt covenants from increasing leverage. If this is in fact the case, an additional cost of debt covenants could be the interest expense deductions (and consequently tax savings) the firm forgoes when agreeing to debt covenants that restrict capital structure. This hypothesis could be tested empirically with data on debt covenants used in this study. 


\section{Tables and Figures}

\section{Table 1}

Sample selection

The sample is selected from the Dealscan database provided by Loan Pricing Corporation and the Compustat database provided by Standard \& Poor's.

\section{Selection Criteria}

Firms in Compustat with non-missing values of:

quarterly data items 2, lag2, 14, 23, 36, lag36, 37, lag37, 40, lag40, 42, 44, lag44, 49, lag49, 61, 108, lag108, 118 ;

annual data items 63,64 or 16,50

Firms not covered in Dealscan

Firms covered in Dealscan with at least one financial

covenant

Firms covered in Dealscan during quarters with a deal

outstanding

Firms covered in Dealscan during quarters with a deal

effective and a computed value of SLACK

\section{Firms Firm-qtrs Deals}

$5,082 \quad 96,499 \quad$ N/A

$3,307 \quad 44,704 \quad$ N/A

$1,775 \quad 51,795 \quad 4,038$

$1,775 \quad 35,596 \quad 4,038$

$1,186 \quad 16,651 \quad 2,096$


Table 2

Description of loan data from Dealscan

The table presents descriptive statistics for 4,038 unique deals from the Dealscan database. All deals are required to have at least one financial covenant. Deals per firm represents the number of deals entered into by the firm during the sample period $(n=1,775$ representing the number of firms with deals in the sample). Stated maturity represents the stated maturity (in quarters) of the loan with the longest maturity in the deal. Effective maturity represents the minimum of the time (in quarters) until maturity or the time until the first covenant violation. Deal size is the amount of credit extended to the firm in the deal. Number of covenants is the number of financial covenants contained in the deal. Interest rate spread is the cost of the loan above the base rate (usually LIBOR) in basis points $(n=3,798$ because some deals are missing pricing information in the Dealscan database).

\begin{tabular}{lrrrrr} 
VARIABLE & MEAN & STDEV & \multicolumn{1}{c}{ P25 } & \multicolumn{1}{c}{ P50 } & \multicolumn{1}{c}{ P75 } \\
\hline Deals per firm & 2.27 & 1.56 & 1.00 & 2.00 & 3.00 \\
Stated maturity & 15.94 & 8.86 & 11.33 & 16.00 & 20.00 \\
Effective maturity & 7.91 & 5.80 & 4.00 & 6.00 & 12.00 \\
Deal size (\$millions) & 342.30 & 837.41 & 34.40 & 115.00 & 325.00 \\
Deal size (\% of Total Assets) & 0.31 & 0.30 & 0.12 & 0.24 & 0.41 \\
Number of covenants & 2.96 & 1.22 & 2.00 & 3.00 & 4.00 \\
Interest rate spread (basis points) & 171.61 & 120.65 & 75.00 & 150.00 & 250.00 \\
\hline
\end{tabular}


Table 3

Frequency of various financial covenants.

\begin{tabular}{lccc} 
Type & Frequency & $\begin{array}{c}\text { Percent of Deals } \\
\text { with this } \\
\text { Covenant }\end{array}$ & $\begin{array}{c}\text { Percent of all } \\
\text { Covenants }\end{array}$ \\
\hline Debt to EBITDA & 1,812 & $44.87 \%$ & $17.00 \%$ \\
Fixed Charge Coverage & 1,471 & 36.43 & 13.80 \\
Interest Coverage & 1,335 & 33.06 & 12.53 \\
Tangible Net Worth & 1,100 & 27.24 & 10.32 \\
Net Worth & 975 & 24.15 & 9.15 \\
Leverage & 809 & 20.03 & 7.59 \\
CAPX & 662 & 16.39 & 6.21 \\
Debt to Tangible Net Worth & 634 & 15.70 & 5.95 \\
Current Ratio & 631 & 15.63 & 5.92 \\
Debt Severice Coverage & 445 & 11.02 & 4.18 \\
Senior Debt to EBITDA & 283 & 7.01 & 2.66 \\
EBITDA & 232 & 5.75 & 2.18 \\
Quick Ratio & 162 & 4.01 & 1.52 \\
Debt to Equity & 55 & 1.36 & 0.52 \\
Cash Interest Coverage & 43 & 1.06 & 0.40 \\
Senior Leverage & 5 & 0.12 & 0.05 \\
Loan to Value & 3 & 0.07 & 0.03 \\
\hline
\end{tabular}


Table 4

Estimation of the rate of conformity between taxable income and book income

Model 1 is: $T I_{i t}=a_{0}+\varphi_{1} P T B I_{i t}+\varphi_{2} P T B I_{i t} \cdot C O V F I R M_{i t}+\varepsilon_{i t}$, from Eq. (7). Model $2 \quad$ is: $\quad T I=\alpha_{0}+\omega_{1}\left(P T B I_{i t}-D A C C_{i t}\right)+\omega_{2} D A C C_{i t}+\omega_{3}\left(P T B I_{i t}-D A C C_{i t}\right)$. COVFIRM $_{i t}+\omega_{4}$ DACC $_{i t} \cdot$ COVFIRM $_{i t}+\varepsilon$, from Eq. (8). $T I$ is taxable income estimated from the financial statements as annual current tax expense grossed up by the top statutory tax rate less the change in the firm's net operating loss carryforward balance. $P T B I$ is annual pre-tax book income. $D A C C$ is discretionary accruals calculated by summing the firm's four quarterly estimates of discretionary accruals using the residual from the model presented in Eq. (2). The standard errors in Panel C are clustered by firm and time. $* * *, * *$, and $*$ indicate statistical significance at the $1 \%, 5 \%$, and $10 \%$ level, respectively.

Panel A: Descriptive statistics of variables used in conformity regressions (covenant firms, $N=6,057$ )

\begin{tabular}{lccccl} 
VARIABLE & MEAN & STDEV & P25 & P50 & P75 \\
\hline TI & 0.058 & 0.165 & 0.006 & 0.053 & 0.115 \\
PTBI & 0.070 & 0.137 & 0.015 & 0.075 & 0.136 \\
$($ PTBI-DACC) & 0.065 & 0.166 & 0.001 & 0.076 & 0.148 \\
DACC & 0.004 & 0.087 & -0.036 & -0.003 & 0.032 \\
\hline
\end{tabular}

Panel B: Descriptive statistics of variables used in conformity regressions (non-covenant firms, $N=14,833$ )

\begin{tabular}{lccccl} 
VARIABLE & MEAN & STDEV & P25 & P50 & P75 \\
\hline TI & 0.007 & 0.355 & -0.012 & 0.051 & 0.137 \\
PTBI & 0.010 & 0.272 & -0.041 & 0.064 & 0.147 \\
$($ PTBI-DACC) & 0.009 & 0.299 & -0.059 & 0.063 & 0.165 \\
DACC & 0.002 & 0.106 & -0.048 & -0.005 & 0.040 \\
\hline
\end{tabular}


Table 4 (continued)

Panel C: Conformity regressions

\begin{tabular}{lcc} 
Parameter & Model 1 & Model 2 \\
\hline INTERCEPT & -0.000 & -0.000 \\
PTBI & $(0.004)$ & $(0.004)$ \\
& $0.834^{* * *}$ & \\
(PTBI-DACC) & $(0.029)$ & $0.827^{* * *}$ \\
& & $(0.029)$ \\
DACC & & $0.845^{* * *}$ \\
& & $(0.042)$ \\
PTBI*COVFIRM & $-0.054^{* *}$ & \\
& $(0.026)$ & $-0.073^{* * *}$ \\
(PTBI-DACC) ${ }^{*}$ COVFIRM & & $(0.025)$ \\
& & 0.017 \\
DACC*COVFIRM & & $(0.061)$ \\
\hline Observations & & 20,890 \\
Adjusted R-Square & 20,890 & 0.396 \\
\hline
\end{tabular}


Table 5

Descriptive statistics of variables used in tests of the relation between incremental tax expense and financial reporting pressure.

ITAX is calculated as $I T A X_{i}=\left[D A C C_{i t} \cdot \widehat{\omega}_{2}\right] \cdot \tau_{i t}$ for firms without debt covenants and ITAX $X_{i}=\left[D A C C_{i t} \cdot\left(\widehat{\omega}_{2}+\widehat{\omega}_{4}\right)\right] \cdot \tau_{i t}$ for firms with debt covenants. DACC is discretionary accruals for the quarter estimated as the residual from the regression shown in Eq. (2). $\widehat{\omega}_{2}$ and $\widehat{\omega}_{4}$ are estimated in Table 4, Model 2, and represent the rate of booktax conformity. $\tau_{i t}$ is the firm's marginal tax rate for the year obtained from John Graham (Graham, 1996). SLACK is calculated as the covenant threshold as reported in Dealscan less the actual value from Compustat scaled by the standard deviation of the actual value over the past eight quarters. These values are then ranked into deciles for each covenant. The value of SLACK used is the firm's minimum SLACK decile for each quarter. NEG is an indicator equal to one if the firm's annual earnings are negative, zero otherwise. $N O L$ is an indicator equal to one if the firm has a net operating loss carryforward balance, zero otherwise. $P P \& E$ is the ratio of property plant and equipment to total assets. INTANG is the ratio of intangible assets divided by total assets. Missing values of INTANG are assigned a value of zero. SIZE is the log of total assets. FOPS is equal to one if the firm reports non-zero foreign pre-tax income. $M B$ is the market to book ratio, measured as the firm's market value of equity at the fiscal quarter end divided by the firm's total book equity at the fiscal quarter end. INTEREST EXPENSE is quarterly interest expense divided by beginning total assets. Some values of INTEREST EXPENSE are coded as combined or insignificant in the Compustat database. Thus for INTEREST EXPENSE only, N=14,996 in Panel A and 35,673 in Panel B. TOTAL DEBT is long term debt plus long term debt in current liabilities all divided by beginning total assets.

Panel A: Firm-quarters with financial covenants in the Dealscan database and a loan active during the fiscal quarter $(N=16,531)$

\begin{tabular}{lrrrrc} 
VARIABLE & MEAN & STDEV & P25 & P50 & P75 \\
\hline ITAX & 0.0003 & 0.0120 & -0.0029 & -0.0000 & 0.0026 \\
SLACK & 3.9084 & 2.8259 & 1.0000 & 4.0000 & 6.0000 \\
NEG & 0.1512 & 0.3583 & 0.0000 & 0.0000 & 0.0000 \\
NOL & 0.3305 & 0.4704 & 0.0000 & 0.0000 & 1.0000 \\
PPEE & 0.3514 & 0.2485 & 0.1577 & 0.2778 & 0.4916 \\
INTANG & 0.0644 & 0.1402 & 0.0000 & 0.0000 & 0.0382 \\
FOPS & 0.4499 & 0.4975 & 0.0000 & 0.0000 & 1.0000 \\
SIZE & 6.4864 & 1.6493 & 5.3172 & 6.5033 & 7.6066 \\
MB & 2.6229 & 2.6485 & 1.2678 & 1.9658 & 3.0116 \\
INTEREST EXPENSE & 0.0052 & 0.0038 & 0.0025 & 0.0046 & 0.0070 \\
TOTAL DEBT & 0.2739 & 0.1938 & 0.1425 & 0.2590 & 0.3796 \\
\hline
\end{tabular}


Table 5 (continued)

Panel B: Firms without financial covenants in the Dealscan database $(N=44,212)$.

\begin{tabular}{lccccc} 
VARIABLE & MEAN & STDEV & P25 & P50 & P75 \\
\hline ITAX & -0.0002 & 0.0179 & -0.0033 & 0.0000 & 0.0026 \\
SLACK & N/A & & & & \\
NEG & 0.3493 & 0.4768 & 0.0000 & 0.0000 & 1.0000 \\
NOL & 0.3962 & 0.4891 & 0.0000 & 0.0000 & 1.0000 \\
PPEE & 0.2761 & 0.2279 & 0.0962 & 0.2138 & 0.3880 \\
INTANG & 0.0230 & 0.0892 & 0.0000 & 0.0000 & 0.0000 \\
FOPS & 0.2515 & 0.4339 & 0.0000 & 0.0000 & 1.0000 \\
SIZE & 4.3928 & 2.0893 & 2.9167 & 4.1810 & 5.6559 \\
MB & 3.3411 & 4.2152 & 1.1387 & 2.0043 & 3.7057 \\
INTEREST EXPENSE & 0.0046 & 0.0051 & 0.0004 & 0.0031 & 0.0067 \\
TOTAL DEBT & 0.1886 & 0.3133 & 0.0035 & 0.1311 & 0.3054 \\
\hline
\end{tabular}


Table 6

Test of incremental tax expense and financial reporting pressure from debt covenants.

All coefficients (and standard errors) have been multiplied by 100 to facilitate presentation. COVFIRM is an indicator variable equal to one if the firm had at least one financial covenant outstanding during the fiscal quarter. All other variables are defined in Table 5. Model 1, Model 2, and Model 3 are nested within: ITAX $i t=\alpha_{0}+$ $\alpha_{1} S L A C K_{i t}+\gamma_{1} N E G_{i t}+\gamma_{2} N O L_{i t}+\gamma_{3} P P \& E_{i t}+\gamma_{4} I N T A N G_{i t}+\gamma_{5} F O P S_{i t}+$ $\gamma_{6} S I Z E_{i t}+\gamma_{7} M B_{i t}+\sum_{j} \gamma_{j} I N D U S T R Y_{j}+\sum_{k} \gamma_{k} T I M E_{k}+\varepsilon_{i t}$. Model 4 substitutes COVFIRM for SLACK. Standard errors are presented in parentheses below the coefficient estimates and are clustered by firm and time (Petersen, 2007). ***,**, and * represent statistical significance at the $1 \%, 5 \%$, and $10 \%$ level, respectively.

\begin{tabular}{|c|c|c|c|c|c|}
\hline Parameter & Prediction & Model 1 & Model 2 & Model 3 & Model 4 \\
\hline \multirow[t]{2}{*}{ INTERCEPT } & & $0.108^{* * *}$ & $0.303^{* * *}$ & $-0.194^{*}$ & $-0.447^{* * *}$ \\
\hline & & $(0.034)$ & $(0.079)$ & $(0.100)$ & $(0.023)$ \\
\hline \multirow[t]{2}{*}{ SLACK } & $(-)$ & $-0.020^{* * *}$ & $-0.018^{* * *}$ & $-0.017^{* * *}$ & \\
\hline & & $(0.005)$ & $(0.004)$ & $(0.004)$ & \\
\hline \multirow[t]{2}{*}{ COVFIRM } & $(+)$ & & & & $0.062^{* * *}$ \\
\hline & & & & & $(0.018)$ \\
\hline \multirow[t]{2}{*}{$N E G$} & & & -0.051 & -0.066 & 0.021 \\
\hline & & & $(0.041)$ & $(0.041)$ & $(0.022)$ \\
\hline \multirow[t]{2}{*}{ NOL } & & & -0.021 & -0.019 & -0.006 \\
\hline & & & $(0.033)$ & $(0.034)$ & $(0.016)$ \\
\hline \multirow[t]{2}{*}{ PPEE } & & & -0.024 & 0.026 & 0.035 \\
\hline & & & $(0.068)$ & $(0.093)$ & $(0.041)$ \\
\hline \multirow[t]{2}{*}{ INTANG } & & & 0.057 & $0.274^{* *}$ & $0.143^{*}$ \\
\hline & & & $(0.147)$ & $(0.125)$ & $(0.081)$ \\
\hline \multirow[t]{2}{*}{ FOPS } & & & -0.015 & -0.012 & $4.731^{* * *}$ \\
\hline & & & $(0.026)$ & $(0.025)$ & $(0.260)$ \\
\hline \multirow[t]{2}{*}{ SIZE } & & & $-0.030^{* * *}$ & $-0.035^{* * *}$ & -0.014 \\
\hline & & & $(0.008)$ & $(0.008)$ & $(0.013)$ \\
\hline \multirow[t]{2}{*}{$M B$} & & & 0.007 & 0.008 & -0.010 \\
\hline & & & $(0.006)$ & $(0.006)$ & $(0.006)$ \\
\hline INDUSTRY & & $\mathrm{NO}$ & $\mathrm{NO}$ & YES & YES \\
\hline TIME & & $\mathrm{NO}$ & NO & YES & YES \\
\hline NOBS & & 16,531 & 16,531 & 16,531 & 75,973 \\
\hline Adj RSQ & & 0.002 & 0.004 & 0.029 & 0.051 \\
\hline
\end{tabular}


Table 7

Piecewise non-linear test of incremental tax expense and financial reporting pressure from debt covenants.

All coefficients (and standard errors) have been multiplied by 100 to facilitate presentation. TIGHTSLACK is an indicator variable equal to one if the firm's computed value of $S L A C K$ for the fiscal quarter was less than 2 (in the tightest three groups of covenants), and zero otherwise. MIDSLACK is an indicator variable equal to one if the firm's computed value of $S L A C K$ for the fiscal quarter was greater than or equal to 3, but less than or equal to 6, and zero otherwise. Firms in the loosest three groups of SLACK (with values from 7 to 9) are captured by the intercept. All other variables are defined in Table 5. Model 1, Model 2, and Model 3 are nested within: ITAX $X_{i t}=\beta_{0}+\beta_{1}$ TIGHTSLACK $_{i t}+\beta_{2}$ MIDSLACK $_{i t}+\gamma_{1} N E G_{i t}+\gamma_{2} N_{0} L_{i t}+$ $\gamma_{3} P P \& E_{i t}+\gamma_{4} I N T A N G_{i t}+\gamma_{5}$ FOPS $_{i t}+\gamma_{6}$ SIZE $_{i t}+\gamma_{7} M B_{i t}+\sum_{j} \gamma_{j} I N D U S T R Y_{j}+$

$\sum_{k} \gamma_{k} T I M E_{k}+\varepsilon_{i t}$. Standard errors are presented in parentheses below the coefficient estimates and are clustered by firm and time (Petersen, 2007). ***,**, and * represent statistical significance at the $1 \%, 5 \%$, and $10 \%$ level, respectively.

\begin{tabular}{|c|c|c|c|c|}
\hline Parameter & Prediction & Model 1 & Model 2 & Model 3 \\
\hline \multirow[t]{2}{*}{ INTERCEPT } & & -0.018 & $0.199^{* * *}$ & $-0.283^{* * *}$ \\
\hline & & $(0.046)$ & $(0.075)$ & $(0.100)$ \\
\hline \multirow[t]{2}{*}{ TIGHTSLACK } & $(+)$ & $0.116^{* * *}$ & $0.101^{* * *}$ & $0.083^{* *}$ \\
\hline & & $(0.038)$ & $(0.035)$ & $(0.032)$ \\
\hline \multirow[t]{2}{*}{ MIDSLACK } & $(+)$ & 0.011 & 0.003 & -0.013 \\
\hline & & $(0.030)$ & $(0.028)$ & $(0.028)$ \\
\hline \multirow[t]{2}{*}{$N E G$} & & & -0.050 & $-0.068^{*}$ \\
\hline & & & $(0.041)$ & $(0.041)$ \\
\hline \multirow[t]{2}{*}{ NOL } & & & -0.019 & -0.018 \\
\hline & & & $(0.033)$ & $(0.033)$ \\
\hline \multirow[t]{2}{*}{ PPEE } & & & -0.017 & 0.032 \\
\hline & & & $(0.067)$ & $(0.092)$ \\
\hline \multirow[t]{2}{*}{ INTANG } & & & 0.061 & $0.284^{* *}$ \\
\hline & & & $(0.146)$ & $(0.125)$ \\
\hline \multirow[t]{2}{*}{ FOPS } & & & -0.014 & -0.010 \\
\hline & & & $(0.026)$ & $(0.025)$ \\
\hline \multirow[t]{2}{*}{ SIZE } & & & $-0.031^{* * *}$ & $-0.036^{* * *}$ \\
\hline & & & $(0.008)$ & $(0.008)$ \\
\hline \multirow[t]{2}{*}{$M B$} & & & 0.007 & 0.008 \\
\hline & & & $(0.006)$ & $(0.006)$ \\
\hline INDUSTRY & & $\mathrm{NO}$ & $\mathrm{NO}$ & YES \\
\hline TIME & & NO & NO & YES \\
\hline NOBS & & 16,531 & 16,531 & 16,531 \\
\hline Adj RSQ & & 0.002 & 0.004 & 0.029 \\
\hline
\end{tabular}




\section{Table 8}

Calculation of a lower bound on the cost of private debt covenant violation

The table uses data presented earlier in the analysis to calculate the cost of the incremental tax paid by firms with tight debt covenant slack (tightest three SLACK groups) relative to firms with loose debt covenant slack (loosest three SLACK groups). Because accruals management is akin to borrowing earnings from the future, any incremental tax paid is assumed to be acceleration of tax expense, not the creation of new tax expense. I assume that by accelerating tax each quarter for $t$ quarters, the firm is foregoing the opportunity to make one lump sum payment in quarter $t+1$. Thus, the cost to the firm is in the time value of money, and can be calculated as the present value of an annuity of $\$ X$ for $t$ quarters less the present value of a lump sum of $\$ X^{*} t$ paid at $t+1$. The analysis assumes a constant payment $\$ X$ each period. The time value of money factors are calculated assuming a $2.5 \%$ quarterly interest rate, and eight (six) quarters for the mean (median) firm. All other values are gathered from sources identified in the table.

\begin{tabular}{|c|c|c|c|}
\hline Description & Line & MEAN & MEDIAN \\
\hline TIGHTSLACK coefficient [Table 7, Model 3] & 1 & $0.08 \%$ & $0.08 \%$ \\
\hline $\begin{array}{l}\operatorname{PVA}(t, 2.5 \%)-\$ 1.00^{*} \mathrm{PV}(\mathrm{t}+1,2.5 \%) \text { where } t=8(6) \text { at the } \\
\text { mean (median). }\end{array}$ & 2 & 0.76 & 0.46 \\
\hline $\begin{array}{l}\text { Discounted tax cost over life of loan (implicitly scaled by } \\
\text { lag assets) [line } 1 \times \text { line } 2 \text { ] }\end{array}$ & 3 & $0.06 \%$ & $0.04 \%$ \\
\hline Interest expense (scaled by lag assets) [from Table 5] & 4 & $0.52 \%$ & $0.46 \%$ \\
\hline $\begin{array}{l}\text { Time value of money factor calculated as } \$ 1.00 \\
\operatorname{PVA}(t, 2.5 \%) \text { where } t=8(6) \text { at the mean (median). }\end{array}$ & 5 & 7.17 & 5.51 \\
\hline $\begin{array}{l}\text { Interest Expense over life of loan (implicitly scaled by lag } \\
\text { assets) [line } 4 \times \text { line } 5 \text { ] }\end{array}$ & 6 & $3.73 \%$ & $2.52 \%$ \\
\hline Tax cost as percentage of interest expense [line 3 / line 6] & 7 & $1.70 \%$ & $1.52 \%$ \\
\hline $\begin{array}{l}\text { Cost of debt (in basis points) [from Table } 5 \text { as (interest } \\
\text { expense/long term debt)* } 4 \text { ] }\end{array}$ & 8 & 760.63 & 706.11 \\
\hline $\begin{array}{l}\text { Lower bound on cost of debt covenant violation (basis } \\
\text { points) [line } 7 \times \text { line } 8 \text { ] }\end{array}$ & 9 & 12.92 & 10.72 \\
\hline
\end{tabular}


Table 9

Additional computations of the cost of debt covenant violation, and comparison of the cost of debt covenant violation to various benchmarks

\section{Panel A: Comparison of tax costs to various benchmarks}

In Panel A the cost of violation (basis point) estimates are taken from Table 8, Line 9. Cost as a percentage of loan spread divides the basis points calculated in Table 8 by the mean (median) loan spread reported in Table 2. Tax cost per $\$ 100$ of discretionary accruals is calculated by dividing the discounted tax cost over the life of the loan from line 3 in Table 8 by the present value of the mean discretionary accruals over the life of the loan. The mean discretionary accruals is estimated in unreported regressions similar to Table 7 except the dependent variable is discretionary accruals instead of incremental tax expense.

\begin{tabular}{lcc} 
& MEAN & MEDIAN \\
\hline Cost of violation (basis points) & 12.92 & 10.72 \\
Cost as a percentage of loan spread & $7.53 \%$ & $7.14 \%$ \\
Tax cost per $\$ 100$ of discretionary accruals & $\$ 2.80$ & \\
\hline
\end{tabular}

Panel B: Comparison of tax costs to various benchmarks using the coefficients in Table 6, Model 3 to calculate tax costs instead of the coefficients in Table 7, Model 3 as in Panel A and Table 8

Panel B is similar to Panel A, except the cost of violation (basis points) estimates are derived using the coefficient estimate on SLACK in Table 6, Model 3, and assuming a 5 decile shift in SLACK. That is, line 1 in Table 8 is replaced by .0165\%*5, or .082\%. All other calculations are the same as in Panel A.

\begin{tabular}{lcc} 
& MEAN & MEDIAN \\
\hline Cost of violation (basis points) & 15.45 & 12.81 \\
Cost as a percentage of loan spread & $9.00 \%$ & $8.54 \%$ \\
Tax cost per $\$ 100$ of discretionary accruals & $\$ 3.35$ & \\
\hline
\end{tabular}


Table 9 (continued)

Panel C: Comparison of tax costs to various benchmarks, using firm specific data to calculate the cost of debt covenant violation and the various benchmarks

In Panel C, I substitute as much firm-specific information into Table 8 as possible when making the calculations. First, I compute each firm's average SLACK group over the life of the loan. I then use a decile specific coefficient from the model ITAX $i t=\alpha_{0}+$ $\sum_{k=1}^{10} \alpha_{k} S L A C K D E C I L E_{k}+\gamma_{1} N E G_{i t}+\gamma_{2} N O L_{i t}+\gamma_{3} P P \& E_{i t}+\gamma_{4} I_{N T A N G}+$ $\gamma_{5}$ FOPS $_{i t}+\gamma_{6} S I Z E_{i t}+\gamma_{7} M B_{i t}+\sum_{j} \gamma_{j} I N D U S T R Y_{j}+\sum_{k} \gamma_{k} T I M E_{k}+\varepsilon_{i t}$ as that firm's average quarterly incremental tax expense (i.e., I use the average quarterly incremental tax expense for the average SLACK group that the firm falls into over the life of the loan). Instead of using the pooled mean (or median) effective time to maturity in calculating the value lost due to the time value of money, I use each deal's effective time to maturity. Instead of using the pooled mean (median) interest expense as in Table 8, I use each firm's interest expense. Finally, instead of using the pooled mean (median) cost of debt as in Line 8 of Table 8 , I use each firm's estimated cost of debt. This procedure produces a unique tax cost for each firm. The first row of the panel presents the mean (median) of this distribution. In the second row, each firm's unique cost of violation is compared to its unique spread. The panel reports the mean (median) of the resulting distribution. The last row of the panel is calculated as in Panel A above, except the discretionary accrual model is analogous to the incremental tax model presented in Fig. 1.

\begin{tabular}{lcc} 
& MEAN & MEDIAN \\
\hline Cost of violation (basis points) & 22.72 & 10.78 \\
Relative to Spread & $21.41 \%$ & $6.85 \%$ \\
Tax cost per $\$ 100$ of discretionary accruals & $\$ 2.02$ & $\$ 1.52$ \\
\hline
\end{tabular}


Figure 1

Relation between estimated debt covenant slack (SLACK) and incremental tax expense.

The figure plots the coefficients $\alpha_{k}$ from the following model: ITAX $X_{i t}=\alpha_{0}+$ $\sum_{k=1}^{10} \alpha_{k} S L A C K D E C I L E_{k}+\gamma_{1} N E G_{i t}+\gamma_{2} N O L_{i t}+\gamma_{3} P P \& E_{i t}+\gamma_{4} I_{N T A N G}+$ $\gamma_{5} F_{\text {OPS }}+\gamma_{6}$ SIZE $_{i t}+\gamma_{7} M B_{i t}+\sum_{j} \gamma_{j} I N D U S T R Y_{j}+\sum_{k} \gamma_{k} T I M E_{k}+\varepsilon_{i t}$.

SLACKDECILE is the decile of SLACK, where SLACK is as defined in Table 5. All other variables are defined in Table 5. White markers in the figure indicate the point is statistically different from zero at the 5\% level (standard errors are clustered by firm and time). The thin line is fitted to highlight the downward trend. The trend was tested statistically in Table 6, Models 1-3, and has a statistically significant negative slope.

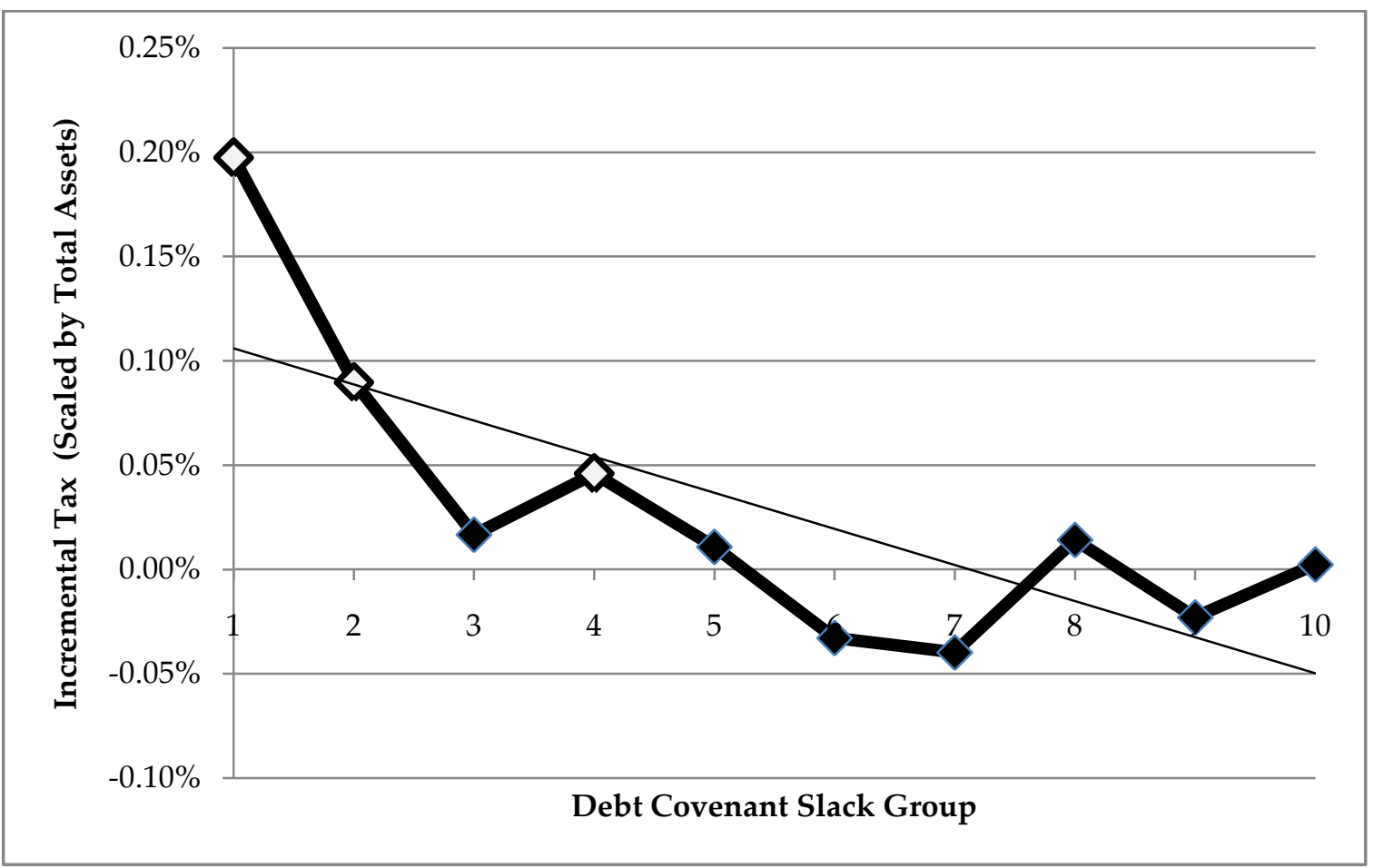


Figure 2

Evolution of incremental tax relative to quarter with the tightest decile of debt covenant slack

In the figure, each quarter where SLACK (as defined in Table 5) is in the tightest group is considered an "event" and firm-quarters are aligned in event time. The window begins four quarters before the event and ends four quarters after.

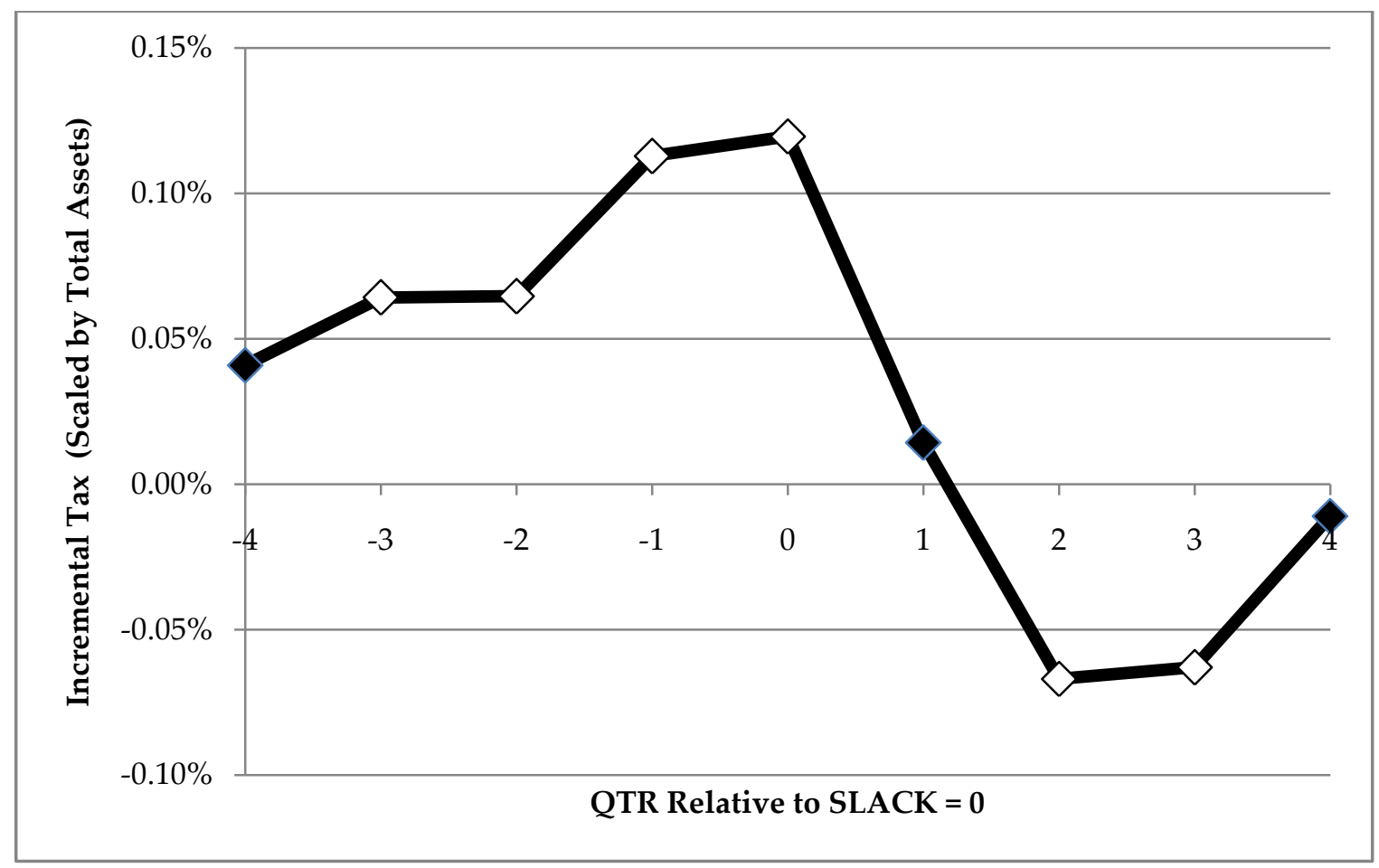




\section{References}

Asquith, Paul, Anne Beatty and Joseph Weber. 2005. "Performance Pricing in Bank Debt Contracts." Journal of Accounting and Economics 40(1-3):101-128.

Badertscher, Brad, John D. Phillips, Morton P. Pincus and Sonja O. Rego. 2007. "Earnings Management Strategies: To Conform or Not to Conform?" Working Paper, University of Notre Dame.

Badertscher, Brad, John D. Phillips, Morton P. Pincus and Sonja O. Rego. 2006. "Tax Implications of Earnings Management Activities: Evidence from Restatements." Working Paper, University of Notre Dame.

Baird, Douglas G., Robert K. Rasmussen. 2006. "Private Debt and the Missing Lever of Corporate Governance." University of Pennsylvania Law Review 154(5):1209-1251.

Balsam, S., Eli Bartov and Carol Marquardt. 2002. "Accruals Management, Investor Sophistication, and Equity Valuation: Evidence from 10-Q Filings." Journal of Accounting Research 40(4):987.

Bartov, Eli, Ferdinand Gul and Judy Tsui. 2000. "Discretionary-Accruals Models and Audit Qualifications." Journal of Accounting \& Economics 30(3):421.

Beatty, Anne, K. Ramesh and Joseph Weber. 2002. "The Importance of Accounting Changes in Debt Contracts: the Cost of Flexibility in Covenant Calculations." Journal of Accounting and Economics 33(2):205-227.

Beatty, Anne, Joseph Weber. 2003. "The Effects of Debt Contracting on Voluntary Accounting Method Changes." Accounting Review 78(1):119.

Beneish, Messod D., and Eric Press. 1993. "Costs of Technical Violation of AccountingBased Debt Covenants." The Accounting Review 68(2):233-257.

Beniesh, Messod D., and Eric Press. 1995. "The Resolution of Technical Default." The Accounting Review 70(2):337:353.

Bonner, Sarah E., Zoe-Vonna Palmrose and Susan M. Young. 1998. "Fraud Type and Auditor Litigation: An Analysis of SEC Accounting and Auditing Enforcement Releases." Accounting Review 73(4):503. 
Boot, Arnoud W. A. 2000. "Relationship Banking: What Do We Know?" Journal of Financial Intermediation 9(1):7-25.

Booth, James R. 1992. "Contract Costs, Bank Loans, and the Cross-Monitoring Hypothesis." Journal of Financial Economics 31(1):25-41.

Bradley, Michael H., Michael R. Roberts. 2004. "The Structure and Pricing of Corporate Debt Covenants." Working Paper, Duke University.

Cloyd, C. B., Jamie Pratt and Toby Stock. 1996. "The Use of Financial Accounting Choice to Support Aggressive Tax Positions: Public and Private Firms." Journal of Accounting Research 34(1):23-43.

DeAngelo, Harry, Ronald W. Masulis. 1980. "Optimal Capital Structure Under Corporate and Personal Taxation." Journal of Financial Economics 8(1):3-29.

Dechow, Patricia M., Richard G. Sloan and A. Sweeney. 1995. "Detecting Earnings Management." Accounting Review 70(2):193-225.

Dechow, Patricia M., Richard G. Sloan and Amy P. Sweeney. 1996. "Causes and Consequences of Earnings Manipulations: An Analysis of Firms Subject to Enforcement Actions by the SEC." Contemporary Accounting Research 13(1):1.

DeFond, Mark L., James Jiambalvo. 1994. "Debt Covenant Violation and Manipulation of Accruals." Journal of Accounting \& Economics 17(1-2):145.

Demerjian, Peter R. W. 2007. "Financial Ratios and Credit Risk: The Selection of Financial Ratio Covenants in Debt Contracts." Working Paper, Emory University.

Dhaliwal, Dan S., Micah Frankel and Robert Trezevant. 1994. "The Taxable and Book Income Motivations for a LIFO Layer Liquidation." Journal of Accounting Research 32(2):278-289.

Dichev, Ilia, Douglas J. Skinner. 2002. "Large-Sample Evidence on the Debt Covenant Hypothesis." Journal of Accounting Research 40(4):1091-1123.

Duke, Joanne C., Herbert Hunt. 1990. "An Empirical Examination of Debt Covenant Restrictions and Accounting-Related Debt Proxies." Journal of Accounting \& Economics 12(1-3):45. 
Engel, Ellen, Merle Erickson, and Edward Maydew. 1999. "Debt-Equity Hybrid Securities.” Journal of Accounting Research 37(2):249-274.

Erickson, Merle, Michelle Hanlon and Edward L. Maydew. 2004. "How Much Will Firms Pay for Earnings That Do Not Exist? Evidence of Taxes Paid on Allegedly Fraudulent Earnings." The Accounting Review 79(2):387.

Graham, John R. 1996. "Proxies for the Corporate Marginal Tax Rate." Journal of Financial Economics 42(2):187-221.

Graham, John R. 2000. "How Big Are the Tax Benefits of Debt?" Journal of Finance 55(5):1901.

Graham, John R., Mark H. Lang and Douglas A. Shackelford. 2004. "Employee Stock Options, Corporate Taxes, and Debt Policy." Journal of Finance 59(4):1585-1618.

Graham, John R., Campbell R. Harvey, and Shiva Rajgopal. 2005. "The Economic Implications of Corporate Financial Reporting." Journal of Accounting and Economics 40(1-3):3-73.

Gramlich, Jeffrey D., William J. Mayew, and Mary Lea McAnally. 2006. "Debt Reclassification and Capital Market Consequences." Journal of Business Finance \& Accounting 33(7) \& (8): 1189-1212.

Gramlich, Jeffrey D., Mary Lea McAnally, and Jacob Thomas. 2001. "Balance Sheet Management: The Case of Short-Term Obligations Reclassified as Long-Term Debt." Journal of Accounting Research 39(2): 283-295.

Hanlon, Michelle. 2003. "What Can We Infer about a Firm's Taxable Income from Its Financial Statements?" National Tax Journal 56(4):831-863.

Healy, Paul M., and Krishna G. Palepu. 1990. "Effectiveness of Accounting-Based Dividend Covenants." Journal of Accounting and Economics 12: 97-123.

Hunt, Alister, Susan E Moyer and Terry Shevlin. 1996. "Managing Interacting Accounting Measures to Meet Multiple Objectives: A Study of LIFO Firms." Journal of Accounting and Economics 21(3):339-374.

Johnson, W. Bruce, and Dan S. Dhaliwal. 1988. "LIFO Abandonment." Journal of Accounting Research 26(2):236-272. 
Jones, Jennifer J. 1991. "Earnings Management During Import Relief Investigations." Journal of Accounting Research 29(2):193-228.

Kim, Yangseon, Caixing Liu and S. G. Rhee. 2003. "The Relation of Earnings Management to Firm Size." Working Paper, University of Hawaii.

Kothari, S. P., Andrew J. Leone and Charles E. Wasley. 2005. "Performance Matched Discretionary Accrual Measures." Journal of Accounting and Economics 39(1):163197.

Lee, Sang Whi, and Donald. J. Mullineaux. 2004. "Monitoring, Financial Distress, and the Structure of Commercial Lending Syndicates." Financial Management 33(3):107-130.

Liu, Chi-Chun, and Stephen G. Ryan. 2006. "Income Smoothing over the Business Cycle: Changes in Banks' Coordinated Management of Provisions for Loan Losses and Loan Charge-Offsf from the Pre-1990 Bust to the 1990s Boom." The Accounting Review 81(2):421-441.

Louis, Henock, Dahlia Robinson. 2005. "Do Managers Credibly use Accruals to Signal Private Information? Evidence from the Pricing of Discretionary Accruals Around Stock Splits." Journal of Accounting \& Economics 39(2):361.

Maydew, Edward L., Katherine Schipper, and Linda Vincent. 1999. "The Impact of Taxes on the Choice of Divestiture Method." Journal of Accounting and Economics 28(2):117-150.

Miller, Merton H. 1977. "Debt and Taxes." Journal of Finance 32(2):261-275.

Mills, Lillian F., Kaye J. Newberry. 2001. "The Influence of Tax and Nontax Costs on Book-Tax Reporting Differences: Public and Private Firms." Journal of the American Taxation Association 23(1):1-19.

Mills, Lillian F., Kaye J. Newberry and Garth F. Novack. 2003. "How Well Do Compustat NOL Data Identify Firms with U.S. Tax Return Loss Carryovers?" Journal of the American Taxation Association 25(2):1-17.

Modigliani, Franco, Merton H. Miller. 1963. "Corporate Income Taxes and the Cost of Capital: A Correction." The American Economic Review 53(3):433-443. 
Nini, Gregory P., David C. Smith and Amir Sufi. 2007. "Creditor Control Rights and Firm Investment Policy." Working Paper, University of Chicago.

Palmrose, Zoe-Vonna, Vernon J. Richardson and Susan Scholz. 2004. "Determinants of Market Reactions to Restatement Announcements." Journal of Accounting and Economics 37(1):59-89.

Petersen, Mitchell A., 2007. "Estimating Standard Errors in Finance Panel Data Sets: Comparing Approaches." Review of Financial Studies (Forthcoming).

Petersen, Mitchell A., Raghuram G. Rajan. 1994. "The Benefits of Lending Relationships: Evidence from Small Business Data." Journal of Finance 49(1):3-37.

Plesko, George A. 2007. "Estimates of the Magnitude of Financial and Tax Reporting Conflicts." Working Paper, University of Connecticut.

Press, Eric G., and Joseph B. Weintrop. 1990. “Accounting-Based Constraints in Public and Private Debt Agreements." Journal of Accounting and Economics 12: 65-95.

Rajan, Raghuram G., Andrew Winton. 1995. "Covenants and Collateral as Incentives to Monitor." Journal of Finance 50(4):1113-1146.

Rego, Sonja O. 2003. "Tax-Avoidance Activities of U.S. Multinational Corporations." Contemporary Accounting Research 20(4):805.

Roberts, Michael R., Amir Sufi. 2007a. "Control Rights and Capital Structure: An Empirical Investigation.” Working paper, University of Pennsylvania.

Roberts, Michael R., Amir Sufi. 2007b. "Contingency and Renegotiation of Financial Contracts: Evidence from Private Credit Agreements." Working paper, University of Pennsylvania.

Robinson, Leslie A. 2007. "Costly Income Statement Classification Management." Working Paper, Dartmouth College.

Roychowdhury, Sugata. 2006. "Earnings Management Through Real Activities Manipulation." Journal of Accounting and Economics 42(3):335-370

Shackelford, Douglas A., Terry Shevlin. 2001. "Empirical Tax Research in Accounting." Journal of Accounting and Economics 31(1-3):321-387. 
Skinner, Douglas J. 1997. "Earnings Disclosure and Stockholder Lawsuits." Journal of Accounting and Economics 23(3)249-282.

Smith, Clifford W. and Jerold B. Warner. 1979. "On Financial Contracting. An Analysis of Bond Covenants.” Journal of Financial Economics 7:117-161.

Sweeney, Amy P. 1994. "Debt-Covenant Violations and Managers' Accounting Responses." Journal of Accounting \& Economics 17(3):281.

Teoh, Siew Hong, Ivo Welch, and T. J. Wong. 1998. "Earnings Management and the Long-Run Market Performance of Initial Public Offerings." The Journal of Finance 53(6):1935-1974.

Wang, Sean and Julia D’Souza. 2006. "Earnings Management: The Effect of Accounting Flexibility on R\&D Investment Choices.” Working Paper, Cornell University.

Watts, Ross L., Jerold L. Zimmerman. 1986. "Positive Accounting Theory." Prentice Hall, Inc.

Zimmerman, Jerold L. 1983. "Taxes and Firm Size." Journal of Accounting and Economics 5:119-149. 